\title{
Article \\ Optimization of Growing Medium and Preservation Methods for Plant Beneficial Bacteria, and Formulating a Microbial Biopreparation for Raspberry Naturalization
}

\author{
Michał Pylak (D), Karolina Oszust and Magdalena Frąc *D \\ Institute of Agrophysics, Polish Academy of Sciences, Doświadczalna 4, 20-290 Lublin, Poland; \\ m.pylak@ipan.lublin.pl (M.P.); k.oszust@ipan.lublin.pl (K.O.) \\ * Correspondence: m.frac@ipan.lublin.pl; Tel.: +48-81-744-50-61
}

Citation: Pylak, M.; Oszust, K.; Frąc, M. Optimization of Growing Medium and Preservation Methods for Plant Beneficial Bacteria, and Formulating a Microbial Biopreparation for Raspberry Naturalization. Agronomy 2021, 11, 2521. https://doi.org/ 10.3390/agronomy11122521

Academic Editor: Sung-Cheol Koh

Received: 24 October 2021

Accepted: 10 December 2021

Published: 12 December 2021

Publisher's Note: MDPI stays neutral with regard to jurisdictional claims in published maps and institutional affiliations.

Copyright: (c) 2021 by the authors. Licensee MDPI, Basel, Switzerland. This article is an open access article distributed under the terms and conditions of the Creative Commons Attribution (CC BY) license (https:// creativecommons.org/licenses/by/ $4.0 /)$.

\begin{abstract}
The current study focuses on the optimization of bacterial growing medium composition, including the carbon and nitrogen source in different concentrations, the $\mathrm{pH}$ value of the medium and the temperature. Optimization was performed for four environmental bacterial isolates belonging to the genera Arthrobacter, Pseudomonas and Rhodococcus, which were previously obtained from wild raspberries. These bacteria proved to be potent antagonists against certain fungal and fungal-like plant pathogens. Furthermore, three preservation methods and three sample preparation techniques were evaluated. In addition, a prebiotic supplementary blend based on previous research was tested. The research included a pot experiment to estimate the influence of bacterial cultures on the growth of plant shoots and roots, on the soil enzymatic activity and the content of macronutrients, minerals and nitrogen in the soil depending on the naturalization strategy. The best carbon and nitrogen source were chosen. The addition of a supplementary blend resulted in the increased growth of two bacterial isolates. Bacterial inoculum applied to the roots and watering resulted in increased shoot mass in objects infected with plant pathogens, although in plants without the pathogen infection, bacterial inoculum resulted in the decreased mass of plants. Naturalization strategy should be matched to the pathogens present at plantations.
\end{abstract}

Keywords: biopreparation; organic farming; fungal plant pathogens; optimization; preservation; pot experiment

\section{Introduction}

Microorganisms have been utilized more and more often in recent years for plant growth and resistance stimulation, which includes biocontrol, as well as soil microbial activity and functionality maintenance or improvement. Bacterial biopreparations and bioproducts are now common in organic farming. Current trends in plant cultivation and pest control are shifting towards methods safe for the environment and microbial diversity [1]. The European Union promotes the use of organic methods of crop production, including pest control, but also bans compounds that are damaging to environmental biodiversity and are detrimental to soil microbial communities [2]. The European Union Biodiversity Strategy for 2030 clearly states that ecological biodiversity degradation must be stopped and one of the most important factors for achieving this goal is agricultural and horticultural production systems based on natural solutions, including beneficial microbes, as well as decreasing the application of mineral fertilizers and reducing the application of chemicals used in pest control. Furthermore, WE No. 834/2007 states that using chemical pesticides must be limited to the absolute minimum and that farmers are encouraged to use substances of natural origin [3]. Biopreparations may consist of microorganism inoculum, a carrier and supplements that support the growth of beneficial microorganisms and their survivability in different ecological niches [4,5]. Biopreparations are products composed of living microorganisms or their metabolites. Currently, there are biopreparations available to farmers, i.e., Micosat F 
or Polyversum WP based, respectively, on the fungi Trichoderma spp. and Pythium oligandrum. There are other biopreparations available that inhibit the growth of soft fruit pathogens such as Phytophthora spp. (PREV-AM), Colletotrichum spp. (chitosan), and Verticillium spp. (Bioczos S) [6-8]. However, there is still a niche available for another agroecology product, combining plant growth and resistance stimulation, as well as being appropriate for the maintenance of soil microbial activity and diversity, and thus appropriate for use in the organic production of fruits.

Since the number of plant protection products targeting phytopathogens which are allowed to be used in organic farming is decreasing, because they are being steadily forbidden on an official basis, the demand for new methods of plant protection is rising. The most promising alternatives to these products are biopreparations based on local and highly effective bacterial isolates. The application of bacteria that are locally occurring in wild plants to plants in plantations can be called a naturalization. In our previous research, we isolated and characterized four bacterial isolates belonging to three different genera Arthrobacter sp., Bacillus sp., and Rhodococcus sp., and examined their ability to inhibit the growth of fungal and fungal-like plant pathogens such as Botrytis spp., Colletotrichum spp., Phytophthora spp. and Verticillium spp. Moreover, we selected four chemical compounds that have the ability to stimulate bacterial growth and are not metabolized by pathogens and might therefore be used as a supplementary prebiotic blend [5].

In this paper, we focus on the development of biopreparation formulations based on previously isolated and examined bacterial isolates. The experiments conducted concentrated on the optimization of the bacterial growth and drying of bacteria, including testing the prebiotic supplementary blend and pot experiment to examine the influence of selected bacterial isolates on plants and pathogens. The optimization of the growing media can have a high degree of influence over the speed of growth for different microorganisms. Different microorganisms utilize different chemical compounds such as a carbon or nitrogen sources. Environmental isolates may show a preference for different medium $\mathrm{pH}$ values or growing temperatures that are often difficult to predict. Optimization can also influence the production of enzymes or other metabolites [9-11]. Preservation methods may differ for different bacterial species. Appropriate preservation techniques ensure that survivability is maintained and that the biopreparation is stable and the shelf life of the future product is sufficiently long. It is also worth noting that an appropriate choice of carrier may shorten the drying time by increasing the surface area of the dried sample.

The aim of this research was to formulate a biopreparation for plant growth and resistance stimulation for raspberry naturalization, defined as the application of previously chosen beneficial bacterial strains, isolated from natural habitats of wild raspberries. The optimization process of the growing medium was focused on the carbon source, the nitrogen source, the $\mathrm{pH}$ value of the medium, the growing temperature, carrier choice and supplementary blend additive. The optimization of the drying process focused on finding a drying method and sample preparation that ensured the highest degree of survivability. We also examined the influence of pure cultures of those bacteria on raspberry plants in the pot experiment, evaluating the dry mass of shoots, the wet mass of roots, and soil dehydrogenase activity in experiments treated with different types of naturalization strategies using prepared biopreparations. The hypothesis of the presented research is that environmental isolates of bacteria belonging to Arthrobacter, Pseudomonas, and Rhodococcus genera are effective in promoting the early growth of raspberry plants and furthermore are suitable to be a part of biopreparation formulation.

\section{Materials and Methods}

\subsection{Isolation and Identification of Bacterial Strains}

Bacteria were isolated from raspberry roots and soil collected in the following Forest Districts: Łuków, Świdnik, Janów Lubelski, Kraśnik, and Siedlce. A full description of the methodology of the sampling techniques used is presented in Oszust et al. (2020) [12] The bacteria were genetically identified based on a $16 \mathrm{~S}$ rDNA fragment as described in 
Pylak et al. (2020) [5]. The sequences obtained were submitted to the National Center for Biotechnology Information (NCBI) database: Rhodococcus sp. B12/18 (GenBank: MW255650), Pseudomonas sp. B37/18 (GenBank: MW255651), Arthrobacter sp. B58/18 (GenBank: MW255652), Rhodococcus sp. B75/18 (GenBank: MW255653). The antagonistic and metabolic abilities of the isolated strains, including important features for plant growth promotion, were evaluated and presented in previous research [5]. These strains were isolated from the rhizosphere of wild raspberry, taking into account that plant-microbe interactions in the rhizosphere determine plant health, as well as soil productivity and fertility [13].

\subsection{Optimization of the Growing Medium for Bacterial Isolates}

Optimization of the growing media was performed for four isolates of bacteria. The basic medium used for optimization consisted of the residues of beer filtering on diatomite $(1 \mathrm{~L}), \mathrm{NaHPO}_{4}(7 \mathrm{~g} / \mathrm{L}), \mathrm{KH}_{2} \mathrm{PO}_{4}(3 \mathrm{~g} / \mathrm{L}), \mathrm{NH}_{4} \mathrm{Cl}(1 \mathrm{~g} / \mathrm{L})$, and microelements solution (10 mL/L) containing $100 \mathrm{mg} / \mathrm{L} \mathrm{MnCl}_{2} * 4 \mathrm{H}_{2} \mathrm{O}, 50 \mathrm{mg} / \mathrm{L} \mathrm{ZnCl}_{2}, 50 \mathrm{mg} / \mathrm{L} \mathrm{CuCl}_{2} * 2 \mathrm{H}_{2} \mathrm{O}$, $50 \mathrm{mg} / \mathrm{L} \mathrm{CoCl}_{2} * 6 \mathrm{H}_{2} \mathrm{O}$, and $50 \mathrm{mg} / \mathrm{L} \mathrm{Na}_{2} \mathrm{MoO}_{4} * 2 \mathrm{H}_{2} \mathrm{O}$. The optimization process focused on 3 sugars: glucose, lactose and sucrose were tested as additional carbon sources, including 3 different concentrations: $3 \%, 6 \%$ and $9 \%$, and 4 different nitrogen sources: $\mathrm{NaNO}_{3}$, $\mathrm{NH}_{4} \mathrm{NO}_{3},\left(\mathrm{NH}_{4}\right)_{2} \mathrm{SO}_{4}, \mathrm{NH}_{4} \mathrm{Cl}$, including 3 different concentrations: $1 \%, 3 \%$ and $6 \%$. The $\mathrm{pH}$ value was set to 7.2 using $1 \mathrm{M} \mathrm{NaOH}$. A total of $15 \mathrm{~mL}$ of medium subjected to optimization was poured into $50 \mathrm{~mL}$ Erlenmeyer flasks; these were plugged with cellulose stoppers and sterilized at a temperature of $121^{\circ} \mathrm{C}$ for $20 \mathrm{~min}$. After sterilization, the medium in the flasks was inoculated with a $1.5 \mathrm{~mL}$ solution of bacteria in the water, for which the turbidity was set to $90 \%$ of transmittance using a turbidimeter (Biolog ${ }^{\circledR}$, Hayward, CA, USA), which represents the optical density of $0.23-0.28$ (0.23 for B37/18, B75/18 and 0.28 for B12/18, B58/18) McFarland measured with the use of a DEN-1B densitometer (Biosan $\AA$, Riga, Latwia) or absorbance value of $0.1-0.12$ (0.1 for B37/18, B75/18 and 0.12 for B12/18, B58/18) measured at the wavelength of $600 \mathrm{~nm}$ with the use of an Infinite M200PRO spectrophotometer (Tecan ${ }^{\circledR}$, Männedorf, Switzerland). Bacteria used for inoculum preparation were cultured for $48 \mathrm{~h}$ on PDA plates at a temperature of $30^{\circ} \mathrm{C}$. After choosing the best carbon and nitrogen sources and their concentrations, the culturing temperature and $\mathrm{pH}$ value of the medium were subjected to optimization. The following temperatures, $18{ }^{\circ} \mathrm{C}, 24^{\circ} \mathrm{C}, 30^{\circ} \mathrm{C}$, and the set of $\mathrm{pH}$ values $4.5,5.0,5.5,6.0,6.5,7.0,7.5,8.0$ were reviewed. For each of the aforementioned variants, carbon source, nitrogen source, the $\mathrm{pH}$ value of the medium and temperature of cultivation were optimized. After $72 \mathrm{~h}$ of cultivation in the tested conditions, $1 \mathrm{~mL}$ of medium with bacteria was diluted with water using the serial dilution method. From the chosen dilutions $\left(10^{-6}, 10^{-7}, 10^{-8}\right) 100 \mu \mathrm{L}$ was spread on a PDA plate using a sterile cell spreader [14]. The plates were then cultivated for $48 \mathrm{~h}$ at $30^{\circ} \mathrm{C}$. Afterwards, the colonies were counted and the composition of the optimized medium was evaluated.

\subsection{Optimization of the Preservation Method for Bacterial Isolates}

The optimization of the preservation method was performed for bacteria growing on an optimized medium. Three techniques were chosen: D-drying in a conventional dryer (Termaks ${ }^{\circledR}$ TS 9053, Bergen, Norway), VD_drying in a vacuum dryer (Memmert ${ }^{\circledR}$ Vacuum Oven VO49, Büchenbach, Germany) and LF-lyophilization (Labconco ${ }^{\circledR}$ FreeZone 2.5, Kansas City, MO, USA) of the bacterial isolates. For the conventional dryer, the temperature was set at a the level of $35{ }^{\circ} \mathrm{C}$ for the first $24 \mathrm{~h}, 42{ }^{\circ} \mathrm{C}$ for the second $24 \mathrm{~h}$ and $50{ }^{\circ} \mathrm{C}$ for the final $24 \mathrm{~h}$ and the whole drying process took $72 \mathrm{~h}$. Vacuum drying was performed at $30{ }^{\circ} \mathrm{C}$ and a pressure of 50 mbar was applied for $72 \mathrm{~h}$ in the presence of $\mathrm{CaCl}_{2}$ as a drying agent. Lyophilization was performed at a pressure of $0.01 \mathrm{mbar}$ and the temperature of the condenser was set at $-56^{\circ} \mathrm{C}$. There were three methods used for sample preparation for drying. The first one was to dry the whole growing medium with bacteria, the second was the centrifugation of the growing medium and only drying the bacterial residue after the 
removal of the supernatant, and the third involved mixing the whole growing medium and bacteria with the carrier-diatomite. In the centrifugation variant, the bacterial suspension was centrifuged for $10 \mathrm{~min}$ at $2880 \mathrm{RCF}$, then the supernatant was removed and the pellet was subjected to the drying process. In the process of mixing the carrier variant with the medium containing bacteria after culturing, 10\% $(w / w)$ dextrose was added, as Kumar, Mallik and Sarkar (2017) showed that dextrose can increase the survivability of bacteria during the drying process.

Furthermore, the addition of trehalose up to a concentration of $0.1 \mathrm{M}$ in the growing medium and the drying process were evaluated in a similar way to dextrose to increase bacterial survivability $[15,16]$. After culturing the medium was mixed with diatomite CELATOM FW-14 (EP Minerals, Reno, NV, USA) in a 2:1 (w/w) ratio. A later preparation was subjected to drying in the presented conditions. After the drying process was complete, $1 \mathrm{~g}$ of the preparation with bacteria was suspended in water and shaken for at least $20 \mathrm{~min}$, and then diluted with water using the serial dilution method. From the chosen dilutions $\left(10^{-6}, 10^{-7}, 10^{-8}\right), 100 \mu \mathrm{L}$ was spread on the PDA plate using a sterile cell spreader [14]. The plates were then cultivated for $48 \mathrm{~h}$ at $30{ }^{\circ} \mathrm{C}$. Afterwards, the colonies were counted and the composition of the optimized medium was evaluated. Each bacterium was dried in a separate container and each dryer was sterilized via heating up to $200{ }^{\circ} \mathrm{C}$ for $2 \mathrm{~h}$ between batches.

\subsection{Prebiotic Supplementary Blend}

The enhancement of bacterial growth of the 4 tested isolates by the supplementary blend consisting of D-malic acid, N-acetyl-D-glucosamine, $\alpha$-keto-glutaric acid, and $\gamma$ aminobutyric acid (in an equal weight ratio, in total $10 \mathrm{~g} / \mathrm{L}$ ) was evaluated during $144 \mathrm{~h}$ of culturing in liquid culture. The medium used in the experiment was an M9 Minimal Salts medium (Merck, Darmstadt, Germany) with the $10 \mathrm{~mL} / \mathrm{L}$ addition of micronutrient solution $\left(\mathrm{MnCl}_{2}{ }^{*} 4 \mathrm{H}_{2} \mathrm{O}(100 \mathrm{mg} / \mathrm{L}), \mathrm{ZnCl}_{2}(150 \mathrm{mg} / \mathrm{L}), \mathrm{CuCl}_{2} * 2 \mathrm{H}_{2} \mathrm{O}(50 \mathrm{mg} / \mathrm{L}), \mathrm{CoCl}_{2} * 6 \mathrm{H}_{2} \mathrm{O}\right.$ $\left.(50 \mathrm{mg} / \mathrm{L}), \mathrm{Na}_{2} \mathrm{MoO}_{4}{ }^{*} 2 \mathrm{H}_{2} \mathrm{O}(50 \mathrm{mg} / \mathrm{L})\right)$. Culturing took place under aerobic conditions, at $\mathrm{pH} 7.2$, at $28{ }^{\circ} \mathrm{C}$ in $50 \mathrm{~mL}$ flasks, $15 \mathrm{~mL}$ of medium, $105 \mathrm{rpm}$ rotation, and $50 \mu \mathrm{L}$ of $10^{6}$ bacterial cells per flask of inoculum. Control was provided for each isolate culture, which constituted the medium and culture conditions but without the addition of supplements. The cultures were performed in triplicate $(n=3)$. Every $24 \mathrm{~h}, 200 \mu \mathrm{L}$ from each flask was placed in a 96-well plate and the optical density of the bacterial culture at a wavelength of $600 \mathrm{~nm}$ (OD600nm) was measured using a spectrophotometric microplate reader, Infinite M200PRO (Tecan ${ }^{\circledR}$, Männedorf, Switzerland). If flocculation appeared and its severity might have had an influence on the measurement, the samples were lightly homogenized or mixed via pipetting to destroy the aggregates.

In detail, the supplements were as follows: D-malic acid (Nanga ${ }^{\circledR}$, Złotów, Poland), $\mathrm{N}$-acetyl-D-glucosamine (Glentham Life Sciences ${ }^{\circledR}$, Corsham, UK), $\alpha$-keto-glutaric acid (MyProtein ${ }^{\circledR}$, Manchester, UK), and $\gamma$-aminobutyric acid (Ostrovit ${ }^{\circledR}$, Zambrów, Polska). These supplements were chosen according to previous research by [5] concerning certain metabolic characteristics and features of selected bacterial isolates using GEN III plates (Biolog ${ }^{\circledR}$, Hayward, CA, USA).

\subsection{Phytotron Raspberry Pot Experiment}

Seedlings of raspberry (variety Polana) were planted in pots, the diameter of which was $19 \mathrm{~cm}$. Each pot contained $3 \mathrm{~kg}$ of soil collected from the top layer at the organic raspberry field, carefully sieved through a $5 \mathrm{~mm}$ sieve beforehand to remove stones and roots. According to District Chemical and Agricultural Station in Lublin (Lublin, Poland), the soil was classified as dense. The soil was not sterilized to ensure that the conditions were close to natural. One raspberry seedling was planted in one pot, with its roots and shoots trimmed to the same size as the others, which is a standard procedure used by farmers when establishing new raspberry plantations. After planting the surface of the soil was thoroughly covered with a blend of vermiculite and perlite (mixed 1:1) to prevent water loss from the soil due to evaporation. Soil moisture was measured using a method of 
TDR (Time Domain Reflectometry) sensor FOM/mts (ETest, Poland) and kept constant at 18-20\% throughout the experiment. Water was poured into the stands (diameter $23 \mathrm{~cm}$ ) according to the TDR measurement method. The temperature in the phytotron was kept constant at $20-22{ }^{\circ} \mathrm{C}$. The constant photoperiod of the day and night system was set at $16 \mathrm{~h}$ for the day and $8 \mathrm{~h}$ for the night. The duration of the pot experiment was two months (January and February 2020). The pot experiment was set up in triplicate (three pots per variant).

The following five variants of contamination with pathogens (pathosystems) were used: Botrytis cinerea G277/18 (B), Verticillium sp. G296/18 (V), Colletotrichum acutatum G172/18 (C), and Phytophthora sp. G408/18 (P), the variants of all of the above-mentioned tested pathogens, and controls without the addition of pathogen, but with the addition of water instead.

Pathogen inoculation was as follows: $10 \mathrm{~mL}$ of a freshly prepared sterile water suspension of the respective pathogens containing $10^{8}$ conidia per $\mathrm{ml}$ was applied per each pot in the case of a single pathogen variant $(B, V, C, P)$. For all of the tested pathogen variants, the suspension consisted of $2.5 \mathrm{~mL}$ of $10^{8} / \mathrm{mL}$ conidia of each pathogen applied together. Pathogen inoculum was applied twice during the pot experiment. The first inoculation was performed during raspberry planting (pipetted into the soil near the roots) and the second one month after raspberry planting. In this case, the Phytophthora sp. and Verticillium sp. suspension were introduced to the soil near the roots, while Botrytis cinerea and Colletotrichum acutatum were inoculated on the plant using sterile inoculation sticks.

For every variant of pathogen contamination, four methods of naturalization strategy, including the application of beneficial bacterial strains selected from natural habitats of wild raspberries, were tested. These options correspond to situations in which biopreparations might be used in the future. The first (R) was to apply the bacterial consortium on the roots of plants during planting in pots - this method might be used when setting up a new raspberry plantation. The second was to apply the bacteria both during planting and one month after naturalization watering with the bacterial consortium (RW), which reflects newly set up plantations with both methods being used. The third one (W) corresponds to already existing plantations where it is only possible to apply microorganisms to all plants during watering. The last one was planted without any naturalization to serve as a control. Table A1 presents the experimental design of the pot experiment.

As with the pathogen inoculum, the bacterial consortium was applied in a $10 \mathrm{~mL}$ total volume of bacterial suspension $(2.5 \mathrm{~mL}$ of each bacterial strain) with an abundance of $10^{8} / \mathrm{mL}$ into the soil regardless of the naturalization variant $(\mathrm{R}, \mathrm{RW}, \mathrm{W})$. Bacterial abundance in the inoculum was determined using the Thoma cell counting chamber and verified using serial dilution, spreading $100 \mu \mathrm{L}$ on PCA plates and culturing for $48 \mathrm{~h}$ at $30{ }^{\circ} \mathrm{C}$. After that time, colonies were counted and based on their number the number of bacteria in the inoculum was confirmed.

To obtain the appropriate number of bacteria for the pot experiment, the tested isolates were cultured on an optimized medium for 4 days. Then, the required concentration was provided through serial dilution, based on Thom's cell counting chamber results (BLAUBRAND ${ }^{\circledR}$, Wertheim, Germany).

After the experiment, soil, root and plant samples were collected, measured and stored for future analysis. The soil samples to be used for soil analyses were stored at $4{ }^{\circ} \mathrm{C}$. Root and shoot samples were weighed and dried, and then stored at room temperature.

\subsection{Plant and Soil Analyses}

The physicochemical analyses of plant and soil material from the pot experiment were performed by the District Chemical and Agricultural Station in Lublin (Lublin, Poland), according to standard procedures used in the Station described below.

Plant material (shoots) testing was performed to determine foliar feeding ( $\mathrm{N}, \mathrm{P}, \mathrm{K}, \mathrm{Ca}$, $\mathrm{Mg}$ ). In the soil, there was a determination of the $\mathrm{N}$ mineral content, the $\mathrm{pH}, \mathrm{P}_{2} \mathrm{O}_{5}, \mathrm{~K}_{2} \mathrm{O}$, $\mathrm{Mg}$, the organic carbon and the soil organic matter contents. 
The determination of $\mathrm{P}$ in plant material after mineralization in $\mathrm{H}_{2} \mathrm{SO}_{4}$ and $\mathrm{H}_{2} \mathrm{O}_{2}$ was performed using the vanadomolibdate method (KQ/PB-24) [17]. The method is based on the spectrophotometric measurement of the intensity of the yellow colour of the phosphorus-vanadium-molybdic acid complex, which is formed by orthophosphate and vanadium ions in the presence of molybdate in an acidic environment through the use of a colorimeter.

The determination of $\mathrm{N}$ in plant material was performed through the use of the distillation method after mineralization in $\mathrm{H}_{2} \mathrm{SO}_{4}$ and $\mathrm{H}_{2} \mathrm{O}_{2}$. Determination of nitrogen content consists of converting the amide form of nitrogen into ammonia through mineralization in concentrated sulfuric acid (VI), distilling ammonia from the alkaline medium, absorption in a known volume of a standard sulfuric acid solution, and the titration of excess acid with a standard sodium hydroxide solution (KQ/PB-70) using the Kjeldahl method with Buchi B-324 distillation apparatus and a digital burette.

The amount of $\mathrm{Mg}$ content in raspberry shoots was determined after mineralization in $\mathrm{H}_{2} \mathrm{SO}_{4}$ and $\mathrm{H}_{2} \mathrm{O}_{2}$ (KQJPB-26). The principle of the method consists of measuring the absorption of radiation by magnesium atoms released when the test solution is sprayed into an acetylene-air flame using a Perkin ELMER atomic absorption spectrometer.

The determination of $\mathrm{K}$ and $\mathrm{Ca}$ content in shoots was determined after mineralization in $\mathrm{H}_{2} \mathrm{SO}_{4}$ and $\mathrm{H}_{2} \mathrm{O}_{2}$ (KQ/PB-25). It involved the measurement of radiation emitted by a suitably excited sample. Excitation source-burner; flame-propane-butane air. The equipment used was a Jenway flame photometer.

The determination of nitrate and ammonium content in the soil $\left(\mathrm{N}-\mathrm{NO}_{3}, \mathrm{~N}-\mathrm{NH}_{4}\right)$ was performed using a colorimetric method which involved the use of the SKALAR SCAN ++ SYSTEM flow autoanalyzer after extraction in $1 \% \mathrm{~K}_{2} \mathrm{SO}_{4}(\mathrm{KQ} / \mathrm{PB}-71)$. Nitrate was determined using the nitrogen-reduction method with the use of cadmium. As for ammoniacal nitrogen, the modified Berthelot reaction was used.

The organic carbon content was determined using Tiurin's method with a heating plate and a Titronic R 300 digital burette being used. The soil organic matter (SOM) was evaluated through the use of a weight method using a laboratory balance, SLW 115 dryer and a Nabarthetm muffle furnace [17].

The $\mathrm{pH}$ in $\mathrm{KCl}$ was determined (PN-ISO 10390:1997) using pH-meter CP-505; the phosphorus $\left(\mathrm{P}_{2} \mathrm{O}_{5}\right)$ and potassium content $\left(\mathrm{K}_{2} \mathrm{O}\right)$ were evaluated by following the EgnerRiehm method (PN-R-04022:1996 + Az1:2002), using a Sherwood flame photometer and Genesys 6 spectrophotometer; and the magnesium content was detected through the use of the Schachtschabel method (PN-R-04020:1994 + Az1:2004), using an AAS-3 atomic absorption spectrometer.

At the end of the study, the above-ground part of the plants was cut off, and the dry weight $(\mathrm{g})$, as well as height $(\mathrm{cm})$ of the plants and the number of branches, were determined. Soil adhered to the roots was removed prior to weighing, shaking and washing in distilled water. In addition, the fresh weight $(\mathrm{g})$ of the roots of the plants was measured. Both measurements were carried out using a laboratory balance (RADWAG, WLC 0.6/A1/C/2). All samples were stored at $4{ }^{\circ} \mathrm{C}$ before analysis for about 1 week.

For the determination of the enzymatic activity of fresh soil samples with natural moisture, samples were taken and stored at $4{ }^{\circ} \mathrm{C}$ before analysis. In the soil samples, the activity of dehydrogenase (EC 1.1.1.1) was determined using the Thalmann method [18] and modified by Alef [19] in three repetitions. Formazan equivalents released in the reaction were converted to SI units presented as $\mathrm{cm}^{3} \mathrm{H}_{2}$. All samples were analysed on the same day.

\subsection{Statistical Analysis}

The colony count in the growing medium and the drying method optimization mean value were calculated based on the repetitions. For the analysis of supplementary blend influence, graphs were generated based on the mean value calculated from three replicates. For the early effect of naturalization strategies on plant growth, the mean value and 
standard deviation of dehydrogenase activity in the soil were calculated and a two-way ANOVA with $p<0.05$ was performed to check differences, and Tukey tests were also performed to reveal statistically significant differences between naturalization strategies. For the analysis of the effect of the prebiotic supplement on the growth of bacteria the mean value and standard deviation were calculated and one-way ANOVA with $p<0.05$, $p<0.01$, and $p<0.001$ was performed to check differences, and Tukey tests were also performed to reveal its statistical significance.

\section{Results}

\subsection{Optimization of the Growing Medium}

Optimizing the growing medium for bacterial growth focused on four parameters: carbon source, nitrogen source, culturing temperature and the $\mathrm{pH}$ value of the growing medium. As presented in Table 1, sucrose addition was optimal in supporting bacterial growth. Both glucose and lactose were also utilized by the bacteria. Peptone addition was not crucial, however, as it intensified growth when combined with a 3\% concentration of lactose. In further experiments, a 3\% addition of sucrose without peptone was chosen. The variant with bacteria on the control M9 medium was also considered to compare the growth rate on a classic store-bought medium to the growth achieved on a medium based on supernatant from diatomite used for beer filtration. The number of bacteria growing on the M9 medium was one order of magnitude lower for Arthrobacter sp. B58/18, and similar for the other tested microorganisms when compared to the $3 \%$ sucrose variant.

Table 1. The effect of different carbon sources (glucose, lactose, sucrose), their concentrations 3\%, $6 \%$, $9 \%$ and the addition of peptone on the growth of bacteria in liquid culture. The control was prepared using the M9 minimal medium containing $\mathrm{KH}_{2} \mathrm{PO}_{4} 15 \mathrm{~g} / \mathrm{L}, \mathrm{NaCl}, 2.5 \mathrm{~g} / \mathrm{L}, \mathrm{Na}_{2} \mathrm{HPO}_{4}, 33.9 \mathrm{~g} / \mathrm{L}, \mathrm{NH}_{4} \mathrm{Cl}, 5 \mathrm{~g} / \mathrm{L}$. Rhodococcus sp. B12/18, Pseudomonas sp. B37/18, Arthrobacter sp. B58/18, and Rhodococcus sp. B75/18, $\mathrm{pH}=7.2$, culturing temperature $=30{ }^{\circ} \mathrm{C}$.

\begin{tabular}{|c|c|c|c|c|c|c|c|}
\hline \multicolumn{2}{|c|}{ Carbon Source } & \multicolumn{2}{|c|}{ Peptone Concentration } & \multicolumn{4}{|c|}{ Colony-Forming Units (CFU/mL) } \\
\hline Sugar & Concentration & Additive & Concentration & B12/18 & B37/18 & B58/18 & B75/18 \\
\hline \multirow{6}{*}{ Glucose } & $3 \%$ & \multirow{2}{*}{ Peptone } & $0 \%$ & $2.45 \times 10^{11}$ & $1.50 \times 10^{12}$ & $6.15 \times 10^{10}$ & $5.46 \times 10^{11}$ \\
\hline & $3 \%$ & & $0.20 \%$ & $<10^{8}$ & $1.37 \times 10^{12}$ & $1.80 \times 10^{11}$ & $1.50 \times 10^{12}$ \\
\hline & $6 \%$ & \multirow{2}{*}{ Peptone } & $0 \%$ & $1.00 \times 10^{9}$ & $1.50 \times 10^{12}$ & $3.00 \times 10^{9}$ & $1.25 \times 10^{10}$ \\
\hline & $6 \%$ & & $0.20 \%$ & $6.80 \times 10^{9}$ & $4.45 \times 10^{10}$ & $5.00 \times 10^{8}$ & $1.66 \times 10^{11}$ \\
\hline & $9 \%$ & \multirow{2}{*}{ Peptone } & $0 \%$ & $<10^{8}$ & $<10^{8}$ & $<10^{8}$ & $<10^{8}$ \\
\hline & $9 \%$ & & $0.20 \%$ & $<10^{8}$ & $3.00 \times 10^{9}$ & $<10^{8}$ & $<10^{8}$ \\
\hline \multirow{6}{*}{ Lactose } & $3 \%$ & \multirow{2}{*}{ Peptone } & $0 \%$ & $9.10 \times 10^{11}$ & $7.50 \times 10^{11}$ & $<10^{8}$ & $7.96 \times 10^{11}$ \\
\hline & $3 \%$ & & $0.20 \%$ & $1.50 \times 10^{12}$ & $1.50 \times 10^{12}$ & $1.00 \times 10^{10}$ & $6.25 \times 10^{10}$ \\
\hline & $6 \%$ & \multirow{2}{*}{ Peptone } & $0 \%$ & $7.61 \times 10^{11}$ & $7.50 \times 10^{11}$ & $<10^{8}$ & $<10^{8}$ \\
\hline & $6 \%$ & & $0.20 \%$ & $4.00 \times 10^{10}$ & $5.20 \times 10^{10}$ & $<10^{8}$ & $3.50 \times 10^{9}$ \\
\hline & $9 \%$ & \multirow{2}{*}{ Peptone } & $0 \%$ & $<10^{8}$ & $<10^{8}$ & $<10^{8}$ & $<10^{8}$ \\
\hline & $9 \%$ & & $0.20 \%$ & $<10^{8}$ & $<10^{8}$ & $<10^{8}$ & $<10^{8}$ \\
\hline \multirow{6}{*}{ Sucrose } & $3 \%$ & \multirow{2}{*}{ Peptone } & $0 \%$ & $1.50 \times 10^{12}$ & $1.22 \times 10^{12}$ & $1.50 \times 10^{12}$ & $1.28 \times 10^{12}$ \\
\hline & $3 \%$ & & $0.20 \%$ & $1.50 \times 10^{12}$ & $1.50 \times 10^{12}$ & $1.50 \times 10^{12}$ & $1.50 \times 10^{12}$ \\
\hline & $6 \%$ & \multirow{2}{*}{ Peptone } & $0 \%$ & $1.50 \times 10^{12}$ & $1.50 \times 10^{12}$ & $8.66 \times 10^{11}$ & $1.50 \times 10^{12}$ \\
\hline & $6 \%$ & & $0.20 \%$ & $8.50 \times 10^{9}$ & $5.20 \times 10^{10}$ & $7.00 \times 10^{9}$ & $2.03 \times 10^{11}$ \\
\hline & $9 \%$ & \multirow{2}{*}{ Peptone } & $0 \%$ & $2.24 \times 10^{11}$ & $1.00 \times 10^{10}$ & $1.50 \times 10^{10}$ & $3.29 \times 10^{11}$ \\
\hline & $9 \%$ & & $0.20 \%$ & $2.15 \times 10^{11}$ & $6.20 \times 10^{10}$ & $1.30 \times 10^{10}$ & $1.80 \times 10^{11}$ \\
\hline \multicolumn{4}{|c|}{ Control using M9 medium } & $1.11 \times 10^{12}$ & $1.50 \times 10^{12}$ & $1.42 \times 10^{11}$ & $1.46 \times 10^{12}$ \\
\hline
\end{tabular}

The results presented in Table 2 show that out of all of the tested nitrogen compounds, ammonium nitrate provided the best growth conditions for the bacteria Pseudomonas sp. B37/18 and Arthrobacter sp. B58/18. A 6\% addition of this N source caused bacteria to grow to the highest concentration of $5.20 \times 10^{9}$. Isolate Rhodococcus sp. B12/18 grew in the narrowest 
spectrum of nitrogen compounds and their concentrations, while Rhodococcus sp. B75/18 utilized all tested nitrogen compounds in the broadest spectrum of their concentrations. Ammonium nitrate $\left(\mathrm{NH}_{4} \mathrm{NO}_{3}\right)$ was utilized by a broad spectrum of bacteria, but only in a higher concentration of $6 \%$. For future experiments upon growth optimization, $6 \%$ of $\mathrm{NH}_{4} \mathrm{NO}_{3}$ was chosen as the best nitrogen source for all tested bacteria.

Table 2. The effect of different nitrogen sources $\left(\mathrm{NaNO}_{3}, \mathrm{NH}_{4} \mathrm{NO}_{3},\left(\mathrm{NH}_{4}\right)_{2} \mathrm{SO}_{4}, \mathrm{NH}_{4} \mathrm{Cl}\right)$ and their concentrations of $1 \%, 3 \%, 6 \%$, on the growth of bacteria in a liquid culture. Rhodococcus sp. B12/18, Pseudomonas sp. B37/18, Arthrobacter sp. B58/18, and Rhodococcus sp. B75/18, pH = 7.2, culturing temperature $=30^{\circ} \mathrm{C}$.

\begin{tabular}{cccccc}
\hline \multirow{2}{*}{$\begin{array}{c}\text { Nitrogen Source } \\
\text { Compound }\end{array}$} & \multicolumn{5}{c}{ Colony-Forming Units (CFU/mL) } \\
& Concentration & B12/18 & B37/18 & B58/18 & B75/18 \\
\hline \multirow{2}{*}{$\mathrm{NaNO}_{3}$} & $1 \%$ & $2.50 \times 10^{9}$ & $<10^{8}$ & $6.50 \times 10^{9}$ & $4.4 \times 10^{11}$ \\
& $3 \%$ & $<10^{8}$ & $<10^{8}$ & $<10^{8}$ & $3.1 \times 10^{11}$ \\
& $6 \%$ & $<10^{8}$ & $<10^{8}$ & $<10^{8}$ & $<10^{8}$ \\
\hline & $1 \%$ & $<10^{8}$ & $<10^{8}$ & $1.30 \times 10^{10}$ & $2.05 \times 10^{10}$ \\
$\mathrm{NH}_{4} \mathrm{NO}_{3}$ & $3 \%$ & $<10^{8}$ & $1.10 \times 10^{11}$ & $2.00 \times 10^{10}$ & $2.7 \times 10^{10}$ \\
& $6 \%$ & $5.20 \times 10^{9}$ & $2.23 \times 10^{11}$ & $1.20 \times 10^{10}$ & $2.6 \times 10^{11}$ \\
\hline & $1 \%$ & $3.00 \times 10^{9}$ & $1.00 \times 10^{9}$ & $<10^{8}$ & $<10^{8}$ \\
$\left(\mathrm{NH}_{4}\right)_{2} \mathrm{SO}_{4}$ & $3 \%$ & $1.00 \times 10^{9}$ & $1.50 \times 10^{10}$ & $<10^{8}$ & $<10^{8}$ \\
& $6 \%$ & $4.00 \times 10^{9}$ & $6.00 \times 10^{9}$ & $1.40 \times 10^{10}$ & $3.5 \times 10^{11}$ \\
\hline & $1 \%$ & $4.26 \times 10^{8}$ & $4.50 \times 10^{9}$ & $1.50 \times 10^{9}$ & $6.47 \times 10^{11}$ \\
& $3 \%$ & $<10^{8}$ & $<10^{8}$ & $3.00 \times 10^{9}$ & $5.26 \times 10^{11}$ \\
$\mathrm{NH}_{4} \mathrm{Cl}$ & $6 \%$ & $6.00 \times 10^{9}$ & $4.00 \times 10^{9}$ & $<10^{8}$ & $4.67 \times 10^{11}$ \\
& & & & &
\end{tabular}

As presented in Figure 1, the temperature affected the growth of bacteria. The most optimal temperature for all bacteria was a temperature of $24^{\circ} \mathrm{C}$. The results also indicate that a temperature of $30{ }^{\circ} \mathrm{C}$ provided sufficient growth of bacteria, except B58/18 (Arthrobacter sp.). From all of the bacteria tested, only isolate B12/18 was able to grow in acidic conditions, when the medium had a $\mathrm{pH}$ value of $5.5-6$, and isolate $\mathrm{B} 37 / 18$ grew in a medium with a $\mathrm{pH}$ value of 6.5 . The most optimal $\mathrm{pH}$ values of the optimized medium which allowed for the growth of all examined bacteria ranged between 7 and 8 .
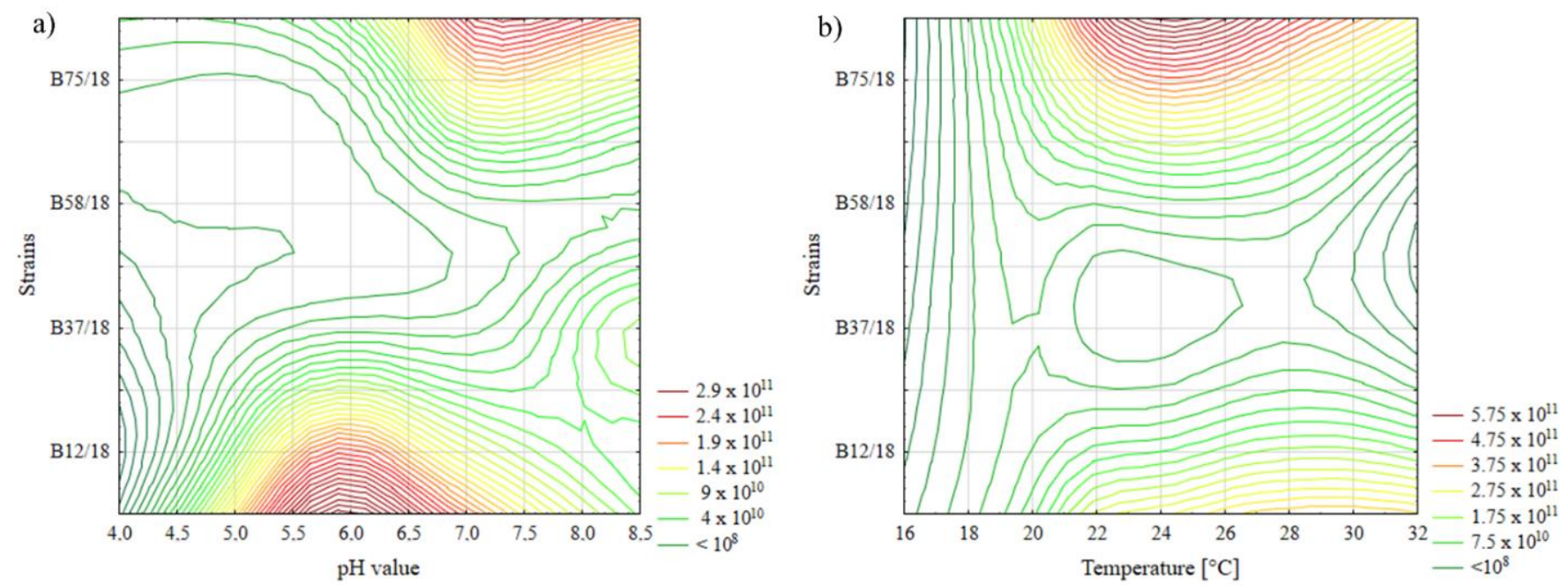

Figure 1. The effect of different medium $\mathrm{pH}$ values-(a) and temperatures-(b) on the growth of bacteria in a liquid culture. Rhodococcus sp. B12/18, Pseudomonas sp. B37/18, Arthrobacter sp. B58/18, Rhodococcus sp. B75/18. 


\subsection{Influence of Bacterial Prebiotic Supplement Addition to the Growing Medium}

The enhancement of growth is presented in Figure 2; this was caused by the $1 \%$ addition of the supplementary blend and was observed for two out of the four tested bacterial isolates growing in the M9 medium. An increase in optical density measured at $600 \mathrm{~nm}$ was observed for Rhodococcus sp. B12/18 and Pseudomonas sp. B37/18. After $100 \mathrm{~h}$ of cultivation, both Arthrobacter sp. B58/18 and Rhodococcus sp. B75/18 isolates began to flocculate, which resulted in the need to lightly homogenize the cultures to destroy the aggregates and ensure the accuracy of the measured optical density. All cultures were lightly homogenized to ensure a similar testing environment. Isolates B58/18 and B75/18 presented similar growth results with or without the prebiotic supplementary blend.
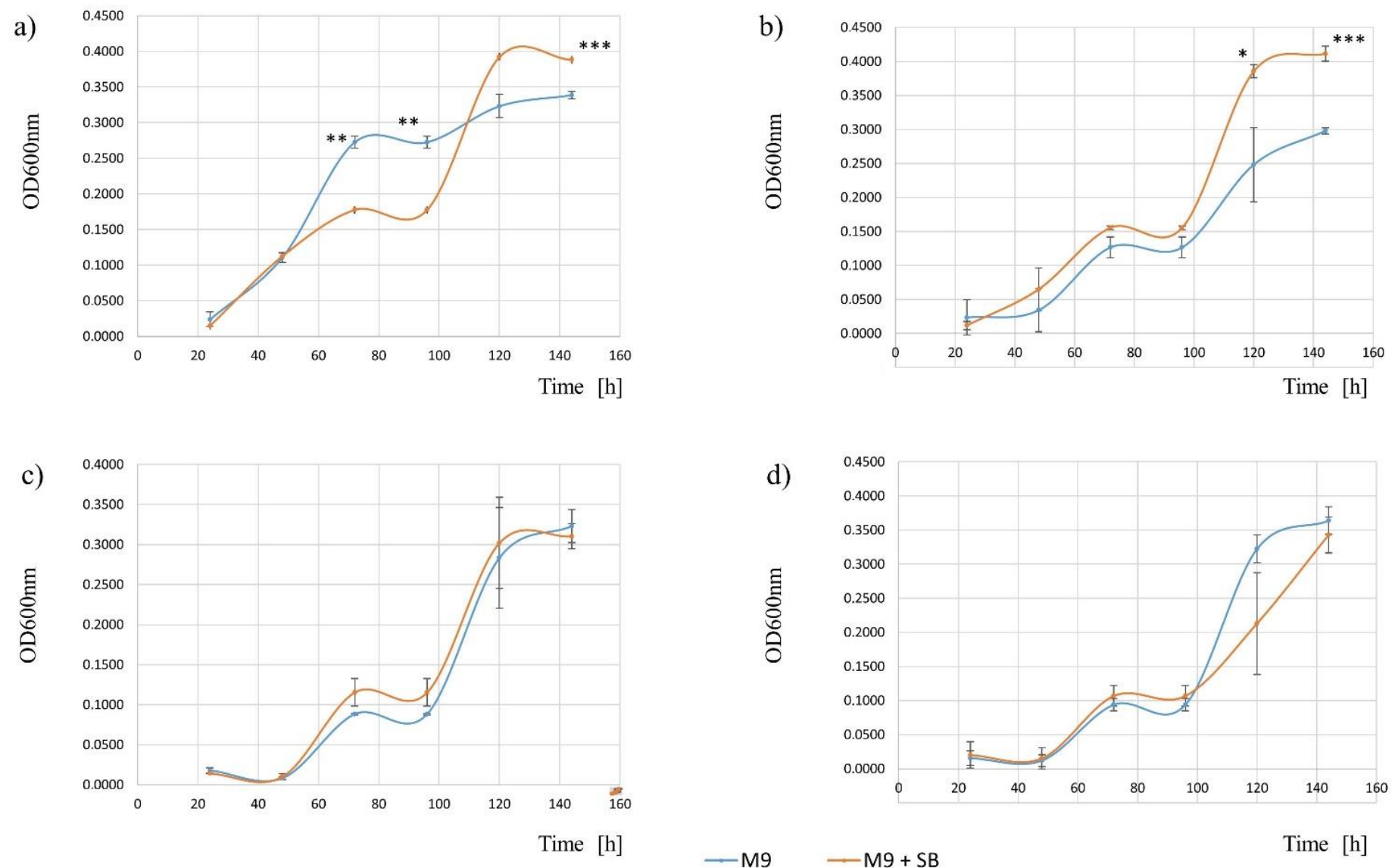

Figure 2. Effect of the $1 \%$ supplementary blend addition (D-malic acid, $\mathrm{N}$-acetyl-D-glucosamine, $\alpha$-keto-glutaric acid, $\gamma$ aminobutyric acid) on the growth of bacteria during $144 \mathrm{~h}$ of culturing in the M9 medium. Figures represent OD600nm measured during cultivation every $24 \mathrm{~h}$ for particular strains of bacteria accordingly: (a) Rhodococcus sp. B12/18, (b) Pseudomonas sp. B37/18, (c) Arthrobacter sp. B58/18, (d) Rhodococcus sp B75/18; $\mathrm{n}=3$, error bars represent standard sample deviation. Stars represent the level of significance ( $p$-value) of the differences within the particular hour. Three stars $-p$-value $<0.001$, two stars $-p$-value $<0.01$, one star- $p$-value $<0.05$.

\subsection{Optimization of Preservation Technique}

In conventional drying (D) of the bacterial pellet, for the medium with bacteria and the medium with bacteria absorbed on diatomite the number of bacteria after drying ranged from $10^{6}-10^{8}$, through to $10^{6}-10^{8}$ to $10^{6}-10^{10}$, respectively. In vacuum drying (VD) of the bacterial pellet, for the medium with bacteria and the medium with bacteria absorbed on diatomite the number of bacteria after drying ranged from $10^{6}-10^{7}$, through to $10^{6}-10^{8}$ to $10^{6}-10^{9}$, respectively. In the lyophilization (LF) of the bacterial pellet, in the medium with bacteria and in the medium with bacteria absorbed on diatomite the number of bacteria after drying ranged from $10^{6}$ to $10^{8}$ depending on the sample preparation strategy. 
All drying techniques, including D—drying, VD—vacuum drying, and LF-lyophilization, and sample preparation had a significant influence on the survivability of the bacteria. The controls included fresh culture and bacterial pellet after centrifugation at the speed of $2800 \mathrm{rcf}$ for $10 \mathrm{~min}$ to examine the influence of spinning on several viable bacteria in the sample. As presented in Table 3, the number of viable cells after centrifugation was reduced by up to two orders of magnitude, as in the case of Rhodococcus sp. B12/18 or by 5.6 times as for Rhodococcus sp. B75/18. Lyophilization resulted in the lowest decrease in bacterial number in the samples without the differentiation in sample type. Lyophilization of the bacterial pellet resulted in the survival of all tested isolates in a number higher than $10^{6}$. The vacuum drying of the medium with bacteria absorbed on diatomite resulted in the survival of most strains in a number higher than $10^{8}$ except for Rhodococcus sp. B12/18. This type of drying was chosen as the most effective and least costly in terms of energy compared to the other preservation methods, based on the results achieved. Even though lyophilization of the bacterial pellet resulted in improved survivability compared with vacuum drying, its energy cost and difficulty to adapt in commercial processes, when compared to vacuum drying, resulted in the resignation of this method for future research. Further preparation of biopreparation was achieved with the use of vacuum drying.

Table 3. The effect of different drying methods and sample preparations on the survivability of bacteria used in naturalization biopreparation. Rhodococcus sp. B12/18, Pseudomonas sp. B37/18, Arthrobacter sp. B58/18, Rhodococcus sp. B75/18, Ddrying, VD—vacuum drying, LF-lyophilization.

\begin{tabular}{|c|c|c|c|c|c|}
\hline \multirow{2}{*}{\multicolumn{2}{|c|}{ Drying Technique and Sample Type }} & \multicolumn{4}{|c|}{ Colony-Forming Units (CFU/g) } \\
\hline & & B12/18 & B37/18 & B58/18 & B75/18 \\
\hline \multirow{2}{*}{ Control } & Fresh culture & $7.50 \times 10^{10}$ & $6.00 \times 10^{8}$ & $4.10 \times 10^{9}$ & $8.50 \times 10^{9}$ \\
\hline & Bacterial pellet & $1.00 \times 10^{8}$ & $2.00 \times 10^{7}$ & $2.00 \times 10^{8}$ & $1.50 \times 10^{9}$ \\
\hline \multirow{3}{*}{$\mathrm{D}$} & Bacterial pellet & $<10^{6}$ & $<10^{6}$ & $1.00 \times 10^{6}$ & $1.00 \times 10^{8}$ \\
\hline & Medium with bacteria & $<10^{6}$ & $<10^{6}$ & $<10^{6}$ & $1.00 \times 10^{8}$ \\
\hline & $\begin{array}{l}\text { Medium with bacteria } \\
\text { absorbed on diatomite }\end{array}$ & $4.00 \times 10^{10}$ & $1.00 \times 10^{6}$ & $9.90 \times 10^{8}$ & $<10^{6}$ \\
\hline \multirow{3}{*}{ VD } & Bacterial pellet & $<10^{6}$ & $<10^{6}$ & $1.00 \times 10^{7}$ & $2.00 \times 10^{7}$ \\
\hline & Medium with bacteria & $2.00 \times 10^{8}$ & $<10^{6}$ & $<10^{6}$ & $<10^{6}$ \\
\hline & $\begin{array}{l}\text { Medium with bacteria } \\
\text { absorbed on diatomite }\end{array}$ & $<10^{6}$ & $5.30 \times 10^{9}$ & $7.00 \times 10^{8}$ & $4.70 \times 10^{9}$ \\
\hline \multirow{3}{*}{$\mathrm{LF}$} & Bacterial pellet & $7.00 \times 10^{6}$ & $1.00 \times 10^{7}$ & $2.00 \times 10^{6}$ & $2.00 \times 10^{8}$ \\
\hline & Medium with bacteria & $3.00 \times 10^{8}$ & $<10^{6}$ & $1.00 \times 10^{7}$ & $1.00 \times 10^{8}$ \\
\hline & $\begin{array}{l}\text { Medium with bacteria } \\
\text { absorbed on diatomite }\end{array}$ & $7.00 \times 10^{8}$ & $<10^{6}$ & $1.00 \times 10^{6}$ & $1.00 \times 10^{8}$ \\
\hline
\end{tabular}

The effect of the addition of trehalose to the culturing of bacteria subject to conventional drying (D) is presented in Table 4. The results show an increase in the units (CFU) of Arthrobacter sp. B58/18 after drying by one order of magnitude from $10^{8}$ to $10^{9}$. The addition of trehalose to the culturing of bacteria subjected to vacuum drying (VD) resulted in an increase in CFU for Rhodococcus sp. B75/18 after drying by one order of magnitude, from $10^{9}$ to $10^{10}$. The addition of trehalose both for the culturing and drying of bacteria subjected to conventional drying (D) resulted in a survival rate that ranged from $10^{7}$ to $10^{8}$ for Rhodococcus sp. B12/18 and Arthrobacter sp. B58/18, respectively. The addition of trehalose to the culturing and drying of bacteria subjected to vacuum drying (VD) resulted in a survival rate that ranged from $10^{8}$ to $10^{9}$ for Pseudomonas sp. B37/18 and Rhodococcus sp. B75/18, respectively. Comparing the CFU after the conventional drying (D) of mixed batches combining Rhodococcus sp. B12/18 and Arthrobacter sp. B58/18 with the trehalose added only during culturing and for both culturing and drying, it may be noted that the results were $1.50 \times 10^{9}$ and $1.67 \times 10^{8}$, respectively. However, from the CFU after the vacuum drying (VD) of mixed batches that combined Pseudomonas sp. B37/18 and Rhodococcus sp. B75/18 with the trehalose added only 
during culturing and during both culturing and drying, it may be noted that the results were $3.97 \times 10^{9}$ and $8.87 \times 10^{9}$, respectively.

Table 4. The effect of trehalose addition and the chosen drying methods on bacterial survivability in drying (D) and vacuum drying (VD) processes used in manufacturing and in the naturalization biopreparation. Rhodococcus sp. B12/18, Pseudomonas sp. B37/18, Arthrobacter sp. B58/18, Rhodococcus sp. B75/18, D—drying, VD—vacuum drying.

\begin{tabular}{|c|c|c|c|c|}
\hline \multirow{2}{*}{ Bacterial Isolate } & \multicolumn{2}{|c|}{ Trehalose Addition } & \multirow{2}{*}{$\begin{array}{c}\text { Drying } \\
\text { Technique }\end{array}$} & \multirow{2}{*}{$\begin{array}{c}\text { Colony-Forming } \\
\text { Units (CFU/g) }\end{array}$} \\
\hline & To the Culture & To Drying & & \\
\hline $\mathrm{B} 12 / 18$ & $0.1 \mathrm{M}$ & - & $\mathrm{D}$ & $<10^{7}$ \\
\hline $\mathrm{B} 58 / 18$ & $0.1 \mathrm{M}$ & - & $\mathrm{D}$ & $1.20 \times 10^{9}$ \\
\hline B37/18 & $0.1 \mathrm{M}$ & - & VD & $2.00 \times 10^{8}$ \\
\hline $\mathrm{B} 75 / 18$ & $0.1 \mathrm{M}$ & - & VD & $1.96 \times 10^{10}$ \\
\hline $\mathrm{B} 12 / 18$ & $0.1 \mathrm{M}$ & $0.1 \mathrm{M}$ & $\mathrm{D}$ & $<10^{7}$ \\
\hline B58/18 & $0.1 \mathrm{M}$ & $0.1 \mathrm{M}$ & $\mathrm{D}$ & $1.00 \times 10^{8}$ \\
\hline $\mathrm{B} 37 / 18$ & $0.1 \mathrm{M}$ & $0.1 \mathrm{M}$ & VD & $1.00 \times 10^{8}$ \\
\hline $\mathrm{B} 75 / 18$ & $0.1 \mathrm{M}$ & $0.1 \mathrm{M}$ & VD & $5.50 \times 10^{9}$ \\
\hline $\mathrm{B} 12 / 18+\mathrm{B} 58 / 18$ & $0.1 \mathrm{M}$ & - & $\mathrm{D}$ & $1.50 \times 10^{9}$ \\
\hline $\mathrm{B} 37 / 18+\mathrm{B} 75 / 18$ & $0.1 \mathrm{M}$ & - & VD & $3.97 \times 10^{9}$ \\
\hline $\mathrm{B} 12 / 18+\mathrm{B} 58 / 18$ & $0.1 \mathrm{M}$ & $0.1 \mathrm{M}$ & $\mathrm{D}$ & $1.67 \times 10^{8}$ \\
\hline $\mathrm{B} 37 / 18+\mathrm{B} 75 / 18$ & $0.1 \mathrm{M}$ & $0.1 \mathrm{M}$ & VD & $8.87 \times 10^{9}$ \\
\hline
\end{tabular}

The addition of trehalose during culturing increased the survivability of Rhodococcus sp. B75/18 in vacuum drying and Arthrobacter sp. B58/18 during conventional drying.

The addition of trehalose during culturing and after culturing did not produce as much of a significant result as the addition which occurred only during culturing. It is worth mentioning that drying bacteria in mixed batches did not result in a reduction in survivability.

\subsection{The Early Effect of the Bacterial Consortium on Raspberry Plants and on Soil Properties}

The influence of bacterial isolates on raspberry plants was evaluated based on four parameters: dry mass of the shoots which allows for a comparison to be made with regard to plants size, the wet mass of the roots which may correlate with microorganisms influencing the plant rhizosphere, overall soil dehydrogenase activity which is correlated with the influence of the biopreparations on the soil microbial community, and the effect of naturalization strategies on soil micro- and macronutrients content.

\subsubsection{The Early Effect of the Bacterial Consortium on Plant Mass}

As presented in Figure 3, the early effect of the bacterial consortium used on raspberry plants depended on the mass of shoots and differed depending on the variant used, but the bio-stimulating effect of the developed biopreparation was observed in plants that were inoculated with pathogens (Figure A1). In general, the mass of shoots was higher in raspberry plants treated with biopreparation. In the variant with the Botrytis cinerea pathosystem, the highest mass of shoots was measured for watering with the addition of a biopreparation, which suggests that this method of biopreparation application might be the most appropriate choice against $B$. cinerea infection. For the Verticillium sp. inoculation variant, the highest mass was observed for the plants that were treated with biopreparation during planting (Figure 3). 


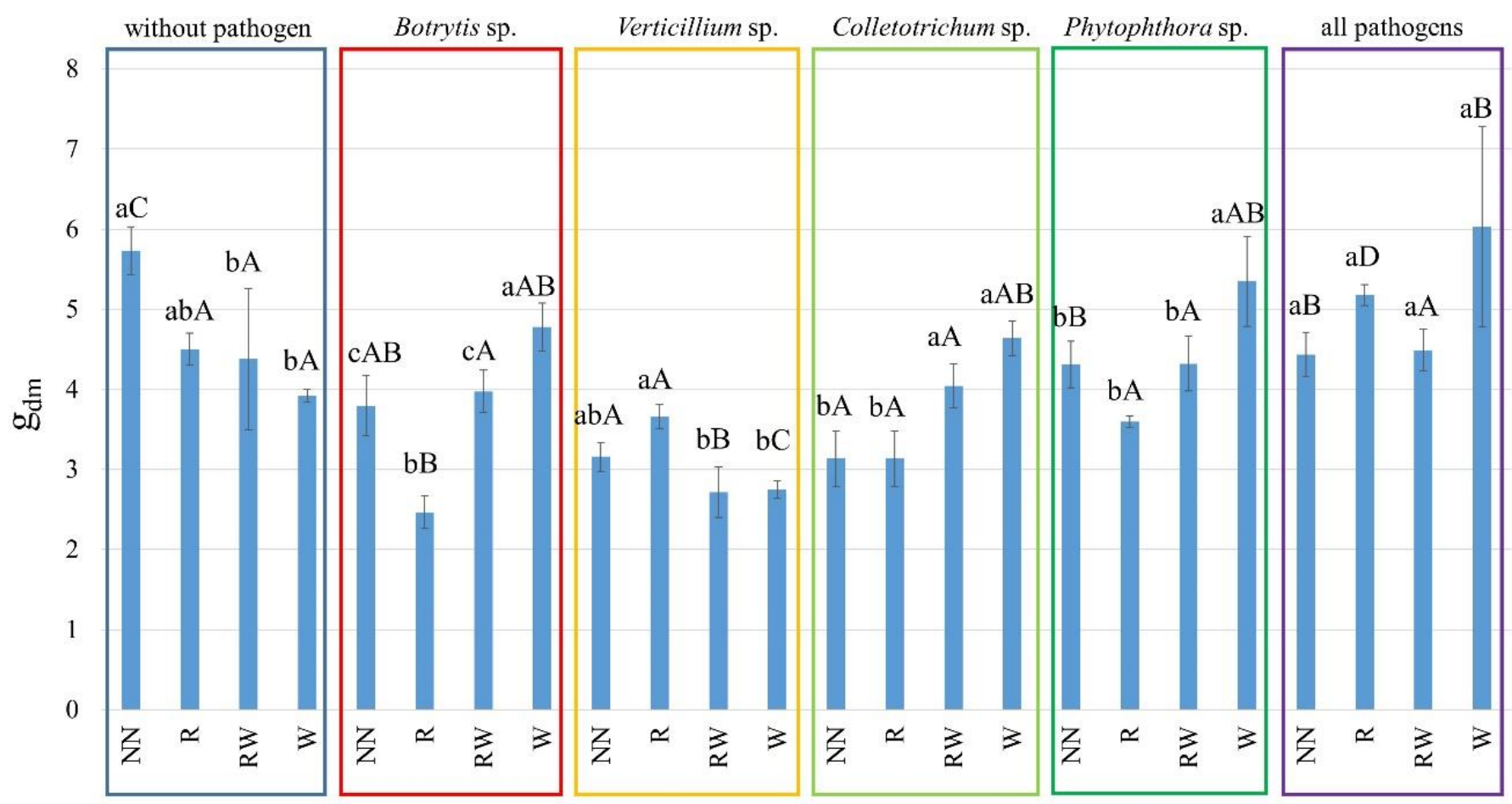

Figure 3. The early effect of the bacterial consortium on Polana raspberry plant growth in the pot experiment depends on the pathosystem and naturalization strategy applied. The dry biomass of shoots varies, according to pathosystems Botrytis cinerea, Verticillium sp., Colletotrichum acutatum, Phytophthora sp., and all pathogens (Botrytis, Verticillium, Colletotrichum, Phytophthora) used and also without pathogens, within different biopreparation application strategies: no naturalization (NN), root inoculations (R), root inoculations and watering (RW), and watering (W). The error bars indicate a standard deviation, $n=3$, different lowercase letters above the bars indicate differences within the particular pathosystems, and different capital letters above the bars indicate differences within the particular naturalization strategies (according to ANOVA with $p<0.05$ ).

Other tested naturalization strategy variants were less successful in inhibiting the negative effect of pathogens on plants. For inhibiting the influence of Colletotrichum acutatum on raspberries, the most effective method was watering with the addition of biopreparation, or this method combined with root naturalization during planting. Only root naturalization had no effect on the plants. Again, for plants inoculated with Phytophthora sp., the most effective method was watering the plants with the addition of biopreparation. Root inoculation during planting without additional treatment was not effective enough. However, the plants that were treated with all four pathogens had the highest dry mass of shoots when watered with the biopreparation. Root naturalization during planting was more effective than no biopreparation or watering naturalization combined with root naturalization.

Appendices $C$ and D Figure A3 present the changes in the number of shoots and the average length of plants for different pathosystems.

\subsubsection{The Early Effect of the Bacterial Consortium Used on Root Mass}

Figure 4 shows that the roots collected from plants that were not inoculated with any pathogens were the heaviest for variants without biopreparation application. Application during planting and application during watering combined with further application with watering was less effective than watering application. Inoculation of the plants with Botrytis cinerea caused a decrease in the mass of the roots compared to the variants without the pathogen. The application of bacterial biopreparation resulted in an increasing mass of roots in the plants that were treated during planting as compared to the plants without any bacterial inoculum applied. In the Verticillium sp. variants, the application of the tested biopreparation during planting or watering caused an increase in root mass in comparison with the application during planting and after that with water. Colletotrichum acutatum increased the mass of 
the root in objects without any naturalization treatment when compared to the control, although the difference was not statistically significant. The application of biopreparation was not effective in plant biostimulation in pathosystem with C. acutatum. In the plants inoculated with Phytophthora sp. root growth was reduced both in the variants without naturalization and when all naturalization strategies were applied. In plants that were inoculated with all 4 pathogens and had no naturalization strategy applied the growth of the roots was decreased in comparison with the objects without any naturalization strategy applied. The most effective method in inhibiting the negative influence of phytopathogens was watering with biopreparation and its application during planting along with subsequent watering with biopreparation.

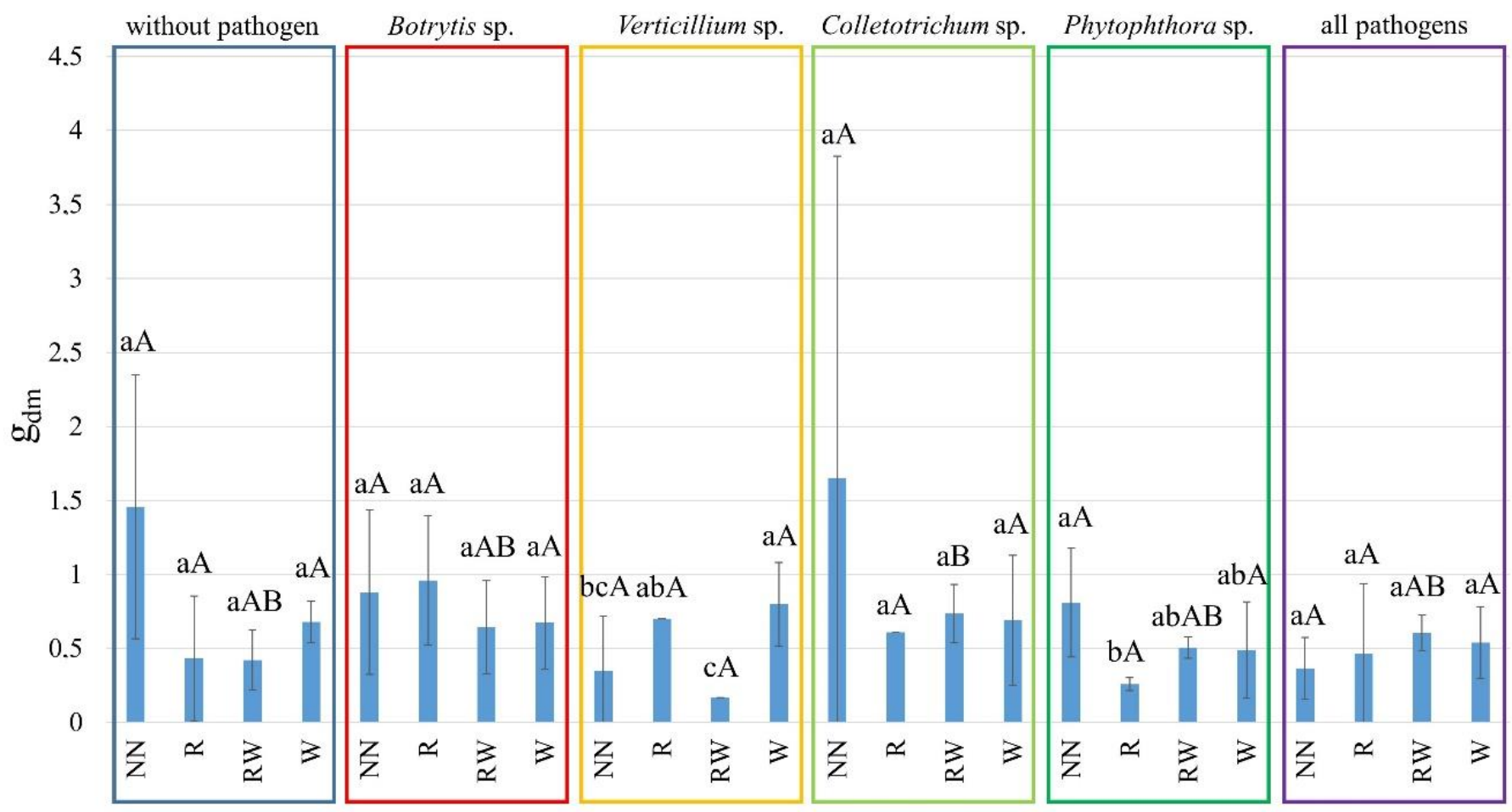

Figure 4. The early effect of the bacterial consortium on Polana raspberry plant growth in the pot experiment depended on the pathosystem and naturalization strategy applied. The wet biomass of the roots, according to pathosystems Botrytis cinerea, Verticillium sp., Colletotrichum acutatum, Phytophthora sp., and all pathogens (Botrytis, Verticillium, Colletotrichum, Phytophthora) and without pathogens, within different biopreparation application strategies: no naturalization (NN), root inoculations (R), root inoculations and watering (RW), and watering (W). The error bars indicate a standard deviation, $n=3$, different lowercase letters above the bars indicate differences within the particular pathosystem, and different capital letters above the bars indicate differences within the particular naturalization strategies (according to ANOVA with $p<0.05$ ).

\subsubsection{The Early Effect of the Bacterial Consortium on Soil Dehydrogenase Activity}

The results of the naturalization strategies with regard to dehydrogenase activity are shown in Figure 5. Both the application of the biopreparation and the presence of a pathogen influenced dehydrogenase activity in the soil. For experiments conducted without the presence of pathogens, dehydrogenase activity was highest in the experiments in which both types of naturalization strategies were applied-root naturalization and watering naturalization. 


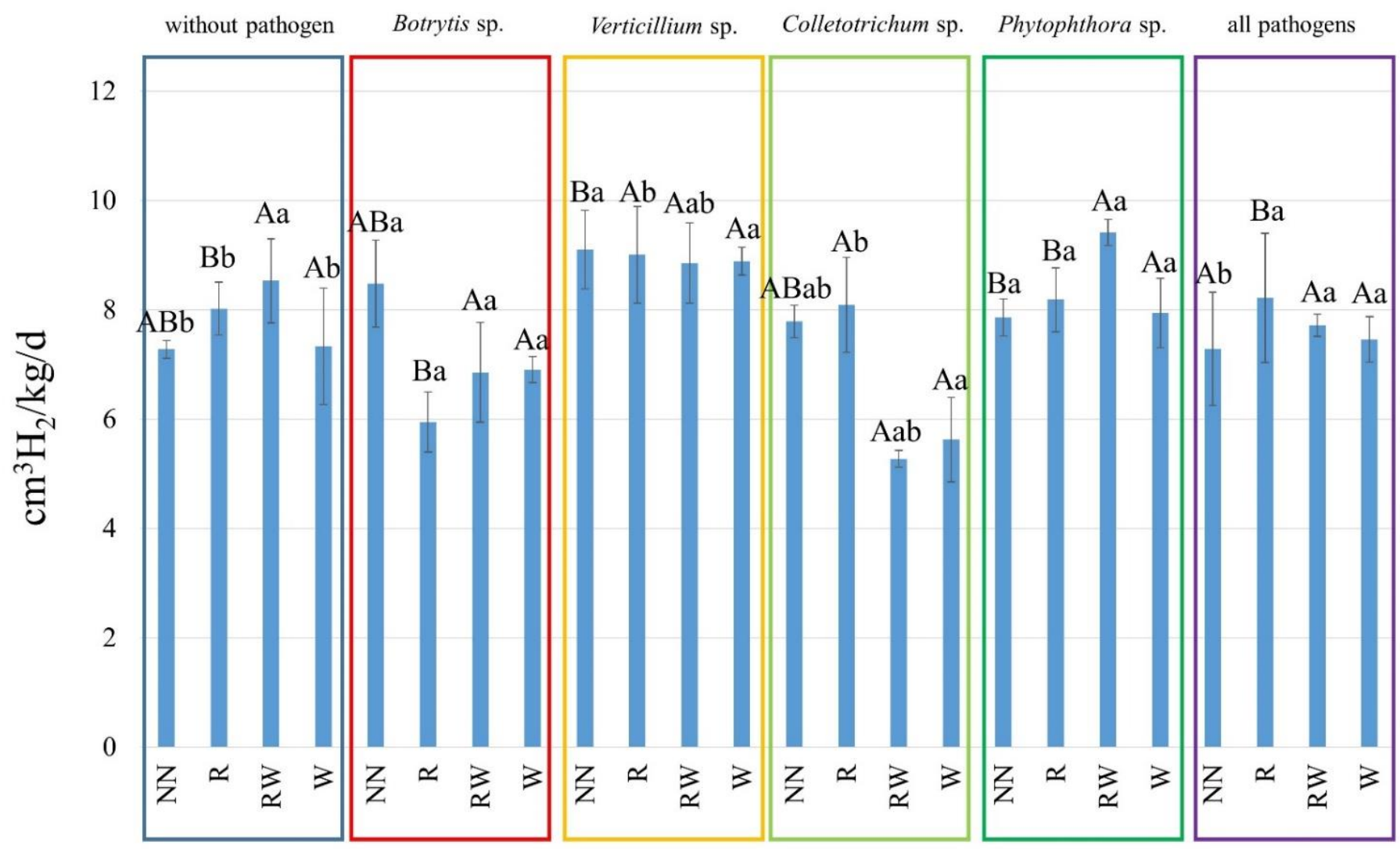

Figure 5. The effect of the bacterial consortium on dehydrogenase activity in the soil samples depending on the pathosystem and naturalization strategy applied. Dehydrogenase activity varied according to the pathosystems used, Botrytis cinerea, Verticillium sp., Colletotrichum acutatum, Phytophthora sp., and all pathogens (Botrytis, Verticillium, Colletotrichum, Phytophthora) and without pathogens, within different biopreparation application strategies: no naturalization (NN), root inoculations $(\mathrm{R})$, root inoculations and watering (RW), and watering (W). Error bars indicate the standard deviation, $n=3$, different lowercase letters above the bars indicate differences within the particular pathosystem, and different capital letters above the bars indicate differences within the particular naturalization strategies (according to ANOVA with $p<0.05$ ).

The second highest activity was observed in naturalization strategies with only root inoculation, while watering with biopreparation resulted in no effect on the dehydrogenase level when compared to the strategies without the naturalization applied. For plants inoculated with Botrytis cinerea, dehydrogenase activity was higher without any naturalization, and a decrease in the dehydrogenase activity to lower levels than in the control was observed after the application of biopreparation. The highest levels of dehydrogenase activity, despite the overall decrease, were observed when both naturalization strategies were applied including watering naturalization and roots naturalization. In experiments carried out in the presence of Verticillium sp., enzymatic activity was comparable to the control regardless of any naturalization strategies, although activities in those objects were the highest among all other trials. In Colletotrichum acutatum, the pathosystem activity of the dehydrogenase was the highest while root naturalization was applied; however, it was only a tendency, without significant differences. Furthermore, both watering naturalization and combined naturalization resulted in reducing dehydrogenase activity in this pathosystem. In experiments involving an inoculation with the fungal-like pathogen Phytophthora sp., a combined naturalization strategy was most effective in increasing dehydrogenase activity. Other application methods had a similar effect and were comparable with the no-naturalization variant. In experiments that were subjected to inoculation with all four pathogens, dehydrogenase activity was the highest for experiments treated with biopreparation during planting. The second highest result was achieved by the 
combined naturalization strategy, and last but not least watering with the addition of the biopreparation.

3.4.4. The Early Effect of the Bacterial Consortium on Soil Macronutrients, Minerals and Nitrogen Content

The amount of macronutrients according to pathosystems Botrytis cinerea, Verticillium sp., Colletotrichum acutatum, Phytophthora sp. and all pathogens (Botrytis cinerea, Verticillium sp., Colletotrichum acutatum, Phytophthora sp.) and without pathogens, within different biopreparation naturalization strategies (no naturalization $(\mathrm{NN})$, root inoculations $(\mathrm{R})$, root inoculations and watering $(\mathrm{RW})$, and watering $(\mathrm{W}))$ was evaluated, and the results are presented in Table 5.

Table 5. The effect of the bacterial consortium on the macronutrient amount in the plant, root and in the soil samples depends on the pathosystem and naturalization strategy applied. The amount of macronutrients varied according to the pathosystem used, Botrytis cinerea, Verticillium sp., Colletotrichum acutatum, Phytophthora sp. and all pathogens (Botrytis, Verticillium, Colletotrichum, Phytophthora) and without pathogens, within different biopreparation application strategies: no naturalization $(\mathrm{NN})$, root inoculations $(\mathrm{R})$, root inoculations and watering $(\mathrm{RW})$, and watering $(\mathrm{W})$.

\begin{tabular}{|c|c|c|c|c|c|c|c|c|c|c|c|c|}
\hline \multirow{2}{*}{$\begin{array}{c}\text { Pathogen } \\
\text { Contamination }\end{array}$} & \multirow{2}{*}{ Naturalization } & \multicolumn{5}{|c|}{ Macronutrients in Shoots } & \multicolumn{3}{|c|}{$\begin{array}{c}\text { Absorbable Forms of } \\
\text { Minerals in the Soil }\end{array}$} & \multicolumn{3}{|c|}{ Nitrogen in Soil } \\
\hline & & \multicolumn{5}{|c|}{$\%$ d.m. } & \multicolumn{3}{|c|}{$\mathrm{mg} / 100 \mathrm{~g}$ Soil } & \multicolumn{2}{|c|}{ mg/kg d.m. } & $\begin{array}{l}\mathrm{N}_{\text {min }} \\
\mathrm{kg} / \mathrm{ha}\end{array}$ \\
\hline \multirow{4}{*}{$\begin{array}{l}\text { without } \\
\text { pathogen }\end{array}$} & NN & 1.44 & 0.29 & 2.47 & 1.22 & 0.44 & 18.3 & 32.5 & 14.3 & 4.41 & 6.26 & 45.90 \\
\hline & $\mathrm{R}$ & 1.44 & 0.3 & 2.63 & 1.38 & 0.48 & 17.6 & 31.8 & 12.9 & 4.18 & 6.34 & 45.20 \\
\hline & RW & 1.4 & 0.27 & 2.15 & 1.2 & 0.48 & 20.3 & 33.9 & 14.5 & 1.41 & 7.87 & 39.90 \\
\hline & W & 1.72 & 0.29 & 2.46 & 1.12 & 0.48 & 20.5 & 34.3 & 15 & 3.33 & 7.10 & 44.80 \\
\hline \multirow{4}{*}{ Botrytis cinerea } & $\mathrm{NN}$ & 1.41 & 0.28 & 2.12 & 1.13 & 0.46 & 19.6 & 35.6 & 12.6 & 3.65 & 7.71 & 48.80 \\
\hline & $\mathrm{R}$ & 1.52 & 0.29 & 2.65 & 1.28 & 0.48 & 20.2 & 35.3 & 12.7 & 10.7 & 3.35 & 60.40 \\
\hline & RW & 1.48 & 0.3 & 2.29 & 1.21 & 0.44 & 21.1 & 36.1 & 13.9 & 3.11 & 7.40 & 45.20 \\
\hline & W & 1.34 & 0.29 & 2.21 & 1.22 & 0.42 & 20.5 & 35.4 & 14.9 & 2.83 & 6.61 & 40.60 \\
\hline \multirow{4}{*}{ Verticilium sp. } & $\mathrm{NN}$ & 1.51 & 0.29 & 2.04 & 1.2 & 0.42 & 16.1 & 31.8 & 14 & 2.23 & 9.37 & 49.90 \\
\hline & $\mathrm{R}$ & 1.66 & 0.3 & 2.31 & 1.16 & 0.4 & 15.5 & 29.8 & 13.5 & 2.75 & 8.02 & 46.30 \\
\hline & RW & 1.65 & 0.29 & 2.35 & 1.15 & 0.32 & 16.1 & 31.7 & 14.6 & 2.45 & 8.94 & 49.00 \\
\hline & W & 1.34 & 0.27 & 2.05 & 1.33 & 0.4 & 18.1 & 33.9 & 14.8 & 1.34 & 8.74 & 37.60 \\
\hline \multirow{4}{*}{$\begin{array}{l}\text { Colletotrichum } \\
\text { acutatum }\end{array}$} & $\mathrm{NN}$ & 1.18 & 0.26 & 2.01 & 1.33 & 0.38 & 17.5 & 31.8 & 12.8 & 2.78 & 7.45 & 44.00 \\
\hline & $\mathrm{R}$ & 1.6 & 0.27 & 2.03 & 1.43 & 0.44 & 18 & 33.1 & 12 & 1.36 & 8.06 & 40.50 \\
\hline & RW & 1.62 & 0.29 & 2.17 & 1.34 & 0.4 & 18 & 33.6 & 13.7 & 9.36 & 3.72 & 56.20 \\
\hline & W & 1.67 & 0.29 & 2.63 & 1.36 & 0.42 & 18.4 & 33.2 & 13.4 & 12.1 & 1.96 & 60.70 \\
\hline \multirow{4}{*}{ Phytophthora sp. } & $\mathrm{NN}$ & 1.6 & 0.28 & 2.56 & 1.36 & 0.4 & 18.5 & 32.3 & 14.4 & 4.40 & 6.61 & 47.30 \\
\hline & $\mathrm{R}$ & 1.47 & 0.24 & 2.14 & 1.3 & 0.38 & 19.7 & 36.7 & 15 & 4.33 & 5.36 & 41.70 \\
\hline & RW & 1.16 & 0.24 & 2.04 & 1.17 & 0.32 & 15.5 & 32.9 & 13.9 & 2.84 & 7.85 & 46.00 \\
\hline & $\mathrm{W}$ & 1.61 & 0.28 & 2.81 & 1.39 & 0.42 & 17.4 & 29.2 & 13.1 & 3.38 & 9.83 & 56.80 \\
\hline \multirow{4}{*}{ all pathogens } & $\mathrm{NN}$ & 1.54 & 0.27 & 2.23 & 1.24 & 0.39 & 16.7 & 30.4 & 12.9 & 4.32 & 9.15 & 57.90 \\
\hline & $\mathrm{R}$ & 1.57 & 0.27 & 2.21 & 1.22 & 0.38 & 14.9 & 28.8 & 13.1 & 4.11 & 9.55 & 58.70 \\
\hline & RW & 1.44 & 0.3 & 2.19 & 1.33 & 0.44 & 16.3 & 32.4 & 13.4 & 4.59 & 7.8 & 53.30 \\
\hline & $\mathrm{W}$ & 1.34 & 0.3 & 2.26 & 1.2 & 0.38 & 18.4 & 34.7 & 13.9 & 2.65 & 9.39 & 51.80 \\
\hline
\end{tabular}

The amount of nitrogen in shoots was the highest in the control experiments without any pathogens, but with the biopreparation applied via watering. For all tested pathosystems, the application on roots during planting caused an increase in the level of nitrogen in the shoots as compared to the experiments without the application of naturalization. Differences in the phosphorus level in the dry mass of the plants were negligible. The amount of potassium in the plants differed between all of the samples studied. The highest level was observed in the Botrytis cinerea pathosystem when roots naturalization was applied and in the Phytophthora sp. pathosystem when watering naturalization was applied. For Botrytis cinerea and Verticillium sp. variants, root application and combined naturalization were the most effective methods. For Colletotrichum acutatum and Phytophthora sp., application via watering was the most effective method, and in both cases levels of this element were higher than in the control. 
The calcium levels were the highest in B. cinerea and C. acutatum pathosystems with roots treated during planting, and in Verticillium sp. and Phytophthora sp. treated during watering. The amount of magnesium in plants was the highest in the control experiments and B. cinerea variants with treated roots. Levels of this element were low in all other pathosystems except for $C$. acutatum experiments treated during planting and experiments with both naturalization strategies applied in pathosystem composed of all four pathogens.

In the control experiments, without the presence of pathogens, the highest amount of absorbable forms of minerals in soil were measured under plants that had been treated using a combined naturalization strategy of watering and the root application of biopreparation, and under plants that were watered with biopreparation.

The number of absorbable forms of minerals in the soil in experiments involving an exposure to pathogens was highest in the $B$. cinerea pathosystem, and in this case, the most effective method was watering with biopreparation. A high amount of minerals in the soil was observed in experiments involving an exposure to Phytophthora sp. with roots treated during planting.

The concentration of nitrogen in the soil was evaluated in terms of its three most important forms: nitrate-nitrogen $\left(\mathrm{N}-\mathrm{NO}_{3}\right)$, ammoniacal nitrogen $\left(\mathrm{N}-\mathrm{NH}_{4}\right)$ and mineral nitrogen $\left(\mathrm{N}_{\min }\right)$. The highest levels of the nitrate form of nitrogen were found in soil samples collected in experiments involving an exposure to Botrytis sp. and naturalized with biopreparation during planting. High levels of this type of nitrogen were found in Phytophthora sp. variants treated with both root naturalization and naturalization watering and variants only treated with naturalization watering. Ammoniacal nitrogen was found in the soil at its highest concentration in samples collected from experiments involving an exposure to Verticillium sp., Phytophthora sp. and all four pathogens treated with both naturalization strategies, watering and roots naturalization, respectively. Mineral nitrogen content was the highest in soil collected from experiments involving an exposure to Botrytis cinerea involving the application of root treatment. Colletotrichum acutatum and Phytophthora sp. pathosystems also contained high levels of soil mineral nitrogen. Experiments involved combined naturalization strategies and watering naturalization for Colletotrichum acutatum and a naturalization for Phytophthora sp., respectively. In the pathosystem including all tested fungal and fungal-like plant pathogens, mineral nitrogen levels were high for variants with roots naturalization, and lower for variants that included watering with a biopreparation, such as the combined and watering naturalization strategies.

\section{Discussion}

\subsection{Optimization of Growing Medium}

The optimization of the growing medium is an essential part of designing any microbial biopreparation to be used in agriculture. This type of process can be applied to reduce the cost of microbial culturing and increase the number of viable cells in the finished biopreparation. This may result in decreasing the costs of the final product and the energy that must be used during the manufacturing processes [20-22]. Additionally, it is important to mention that changes in the growing medium can influence bacterial antagonistic properties against fungal plant pathogens [23]. All of the tested isolates of bacteria were able to utilize all three tested sugars as carbon sources, but sucrose was the only sugar that in the lowest examined concentration of 3\% allowed all four isolates to reach numbers as high as $10^{12}$ in $48 \mathrm{~h}$ of culturing. Peptone addition did not provide any notable advantage which might suggest that the supernatant from diatomite used for beer filtering might contain a source of substances similar to those in peptone, such as an organic nitrogen source, peptides and polypeptides, vitamins and amino acids [24]. Comparing the obtained results of bacterial growth on the proposed medium with a $3 \%$ sucrose content to the commercially available M9 medium, it may be noted that growth on both media is similar with one order of magnitude higher on the tested medium as compared to the M9 medium for Arthrobacter sp. B58/18. 
Ammonium nitrate has been previously proven to be efficient as a carbon source in bacterial growth similar, to other tested mineral nitrogen sources [25-27]. It is a cheap and efficient nitrogen source not only for bacteria but also for plants. It may be assumed that residues of ammonium nitrate in biopreparation can be utilized by bacteria and plants after the application of the biopreparation. It might be critical to evaluate the temperature and $\mathrm{pH}$ value of the culturing medium while optimizing the growing medium, especially for environmental isolates that have not been cultured and fully understood previously. The optimal soil $\mathrm{pH}$ value for most plants and plant-associated bacteria is slightly acidic or neutral. As we have proven for these environmental isolates, the optimal $\mathrm{pH}$ value of the growing medium is in the range between 7 and 8 .

Carefully chosen medium additives have the potential to influence bacterial growth in a very effective way. In previous research we chose four chemical compounds based on their efficient utilization by bacteria [13]. D-malic acid, N-acetyl-D-glucosamine, $\alpha$ keto-glutaric acid, and $\gamma$-amino-butyric acid were added to the medium in a $1 \% \mathrm{~m} / \mathrm{v}$ total concentration. D-malic acid may be a stimulant for soil bacteria since some plants secrete this compound to the soil near their roots to possibly attract plant-growth-promoting bacteria [28]. N-acetyl-D-glucosamine takes part in cell signaling and in the construction of the cell wall $[29,30]$. The $\alpha$-ketoglutaric acid molecule is an antioxidant; this organic acid is also a part of the Krebs cycle and its addition may stimulate bacterial growth [31,32]. The $\gamma$-amino-butyric acid molecule is an amino acid that can be used as a carbon or nitrogen source by some bacterial isolates, e.g., Pseudomonas sp. [33,34]. Although supplement addition was only $1 \%$ of the total medium mass, it had a positive impact on the growth of two isolates-Rhodococcus sp. B12/18 and Pseudomonas sp. B37/18. Two other isolates were not affected by the addition of supplements when compared to the control.

\subsection{The Preservation of Bacteria}

The preservation of bacterial cells to ensure their viability after long-term storage is not an easy task. What is more important is that the isolates used in this study were nonspore-forming Gram-negative bacteria. This makes their preservation much more difficult, and thus it is important to optimize this process correctly, ensuring a broad spectrum of methods, and at the same time it must be borne in mind that this process needs to be scalable to industrial processes. Chosen methods such as conventional drying, vacuum drying and lyophilization are typically used in the preservation of different strains of bacteria. Survivability depends on the type of bacteria and process parameters $[15,35-37]$. This research proved that environmental isolates of non-spore-forming bacteria can be preserved using many methods and sample preparation techniques. It has been proven that spinning bacterial cultures affected the number of viable cells in the medium. Another study indicated that the longer the storage time and the higher the RCF, the more bacteria are destroyed [38].

In this research, centrifugation resulted in a decrease in the number of viable cells, from five times up to over two orders of magnitude. Different sample preparation techniques produce many advantages and disadvantages. Preserving only the bacterial pellet results in a decrease in the drying time due to the removal of most of the water with the supernatant, but also the removal of secondary metabolites and substances that might help bacteria deal with the temperature and moisture stress [39]. Drying the whole medium with the bacteria ensures that the bacteria are surrounded by all of its metabolites and any remaining sucrose that might help bacteria to survive the drying process, but the increasing osmotic pressure caused by removing water from the drying medium might negatively affect bacteria during the drying process. The removal of large amounts of liquid takes more time by lengthening the drying process and subjecting bacteria to longer periods of high temperature [40,41]. The sample that consisted of medium absorbed on diatomite dried far more rapidly than the sample without diatomite due to its much larger surface area. The location of the absorbing medium with bacteria into diatomite results in the bacteria being surrounded by its growing medium, but because diatomite is a very porous material it is a great binder 
to bacteria. However, diatomite is proven to have a negative ion load that may tightly bind bacteria without their ability to escape after biopreparation application [42]. Another advantage of using diatomite in this type of biopreparation is that it is chemically inert and can store large amounts of water, which, after the application of biopreparation, may help both plants and bacteria by improving soil water retention [43]. A classic sample drying resulted in the Maillard reaction and the process took over $72 \mathrm{~h}$. Even though lyophilization was effective in the preservation of almost every sample type and bacterial isolate, due to its energy cost, sample preparation time (freezing), and the small amounts that can be lyophilized at once, it was decided that this type of drying technique will not be used in future biopreparation production. Vacuum drying was chosen as the best option for those particular isolates and for future application in biopreparation manufacturing due to its easy scalability to industrial processes. Furthermore, drying using vacuum drying resulted in the biopreparation having the form of a light and airy powder with few to no harder granules. This may help with ease of use by farmers and may also result in less of a caking tendency.

Trehalose is known to serve a role as a cryoprotectant during lyophilization and microbiological preparation drying. Its ability to both stabilize biomolecules and decrease the negative effect of drought and high temperatures makes it an ideal additive for the preservation of bacterial cells [44,45]. Research by Crove, Reid and Crowe (1996) suggests that trehalose may be superior to other sugars for preserving biomaterials [15,46]. Research has also shown that the addition of trehalose to the growing medium before culturing may stimulate bacteria to prepare for temperature and drought stress, thereby improving their survivability during preservation and enhancing the production of heat shock proteins [47]. The addition of trehalose to growing medium and preparation before drying had an impact on the survivability of some isolates such as Rhodococcus sp. B75/18. Since trehalose may facilitate the drying process, it was included in the final growing medium as one of the components.

\subsection{Effect of Biopreparation on the Early Growth of Plants}

Scientists agree that the early growth period is a crucial time for plants, which can affect their whole life. It is not only important to ensure that the soil is well prepared but also that it is rich in microorganisms that can enhance the growth of young plants such as raspberry seedlings and protect them from pathogens that are present in the soil [48-50]. Soilborne pathogens can be transported from the nursery to newly set up plantations, and from soil to leaves by soil splash that periodically occurs, e.g., during the rain [51,52]. The early effect of selected strains of bacteria on the growth of raspberry plants varied depending on the phytopathogen contamination variant and naturalization strategy. All experiments involving contamination with pathogens benefitted due to naturalization when compared with the experiments conducted without naturalization, in all pathosystems except Phytophthora sp. Additionally, for all pathogens, the highest shoot mass was lower than the control without any pathogens. This leads to the conclusion that the addition of biopreparation to plants infected with pathogens resulted in a higher plant mass compared to experiments without bacterial treatments. Inoculation with pathogens resulted in a decrease in plant mass as compared to the control, which shows that the plants were truly affected by the pathogens. Although the shoot mass suggested that biopreparation may be an important factor in inhibiting the effects of pathogen infection in plants, the mass of the roots decreased in most experiments involving a microbial treatment. All pathogens except Colletotrichum acutatum, which along with Verticillium sp. was inoculated on shoots, caused a decrease in root mass compared with the control. In plants without pathogen infection, naturalization caused a decrease in plant mass. This is an important observation, and may be connected to the stress of plants due to the colonization of plant tissues by microorganisms. However, the experiment was conducted for 8 weeks, which might be not enough to observe the full naturalization effect. It is known that stress-induced bacterial genes are associated with plant-bacterial interactions and plant- 
associated bacteria can coordinate interactions with plants [13]. Therefore, we anticipate that after the first stress, plants will adapt to naturalization conditions and a positive effect will be possible, as was observed in pathosystems combined with naturalization strategies. Moreover, according to the literature [13], in the future there lies great potential in plant growth-promoting microorganisms as inoculants of agricultural soils.

Dehydrogenase activity is often used as an indirect indicator of overall soil microbial activity, because it occurs intracellularly in all living microbial cells and does not accumulate in the soil [53-55]. An increase in enzymatic activity might suggest that the soil microbiota present a high degree of activity and that the soil with the naturalization presents a sufficient medium for microbial life [54,56]. In experiments not involving pathogen infection, dehydrogenase activity was higher than in experiments treated with the naturalization treatment. In all pathosystems except Botrytis cinerea, at least one biopreparation application method caused an increase in soil enzymatic activity. Root naturalization and combined naturalization strategy (root treatment and naturalization watering) were the most effective treatment. This suggests that overall biopreparation has a positive effect on soil microbial communities by enhancing the dehydrogenase activity. It is worth noting that even though Botrytis cinerea and Colletotrichum acutatum were applied to the shoots of raspberries, they negatively affected the soil activity by the highest factor. This might be due to the response of the plant to pathogens and a defensive strategy that might involve secreting chemical compounds affecting microbes in the rhizosphere [57].

The macronutrients content in plant shoots can vary depending on many different factors, such as the stage of growth, the soil microbial community, environmental conditions, and the presence of pests [58-63]. The experiments without pathogen root naturalization resulted in the highest increase in macronutrients in plant shoots. This may be due to an increase in the solubility of compounds near the roots which leads to easier absorption. Root naturalization also proved its effectiveness in the presence of pathogens. It is worth noting that inoculation with Botrytis cinerea caused an increase in the absorbable forms of minerals in soil when compared with the control. Combined naturalization strategies and naturalization watering were the most effective for most of the pathosystems. Microorganisms in the soil may contribute to enhancing the solubility of some compounds that might be beneficial for plants [64]. The amount of nitrogen in the soil was not highly dependent on the tested naturalization strategy, although we found that some particular pathogens increased the amount of nitrogen in soil when compared with the control, especially Verticillium sp. and all pathogens combined. Some research shows that fungal and fungallike plant pathogens such as Phytophthora sp. may benefit from soil nitrogen imbalance and a higher amount of nitrogen in soil may promote the growth of phytopathogens [65].

\section{Conclusions}

- Optimization of bacterial media composition and growing conditions leads to improved growth.

- Supplementary prebiotic additives enhance the growth of bacteria even in low concentrations, such as $1 \%$.

- Vacuum drying growing medium absorbed on diatomite is effective in supporting bacterial survivability. The trehalose additive may be an important factor increasing survivability.

- Soil dehydrogenase activity was positively affected by the biopreparation used in control experiments, and in the presence of pathogens dehydrogenase activity varied.

- Different naturalization strategies affected the amounts of nutrients in the soil and shoots differently.

- Naturalization via watering with bacterial inoculum caused the biostimulation of plant growth through an increase in the mass of shoots in pathosystems with pathogen contamination. Therefore, naturalization strategy should be matched to the pathogens occuring at the plantations. 
Author Contributions: Conceptualization, M.F., K.O. and M.P.; methodology, M.F., K.O. and M.P.; software, M.P.; investigation, M.P. and K.O.; writing-original draft preparation, M.P.; writingreview and editing, M.P., K.O. and M.F.; visualization, M.P.; supervision, M.F.; project administration, M.F.; funding acquisition, M.F. All authors have read and agreed to the published version of the manuscript.

Funding: This research was funded by the National Centre for Research and Development in frame of the project BIOSTRATEG, contract number BIOSTRATEG3/344433/16/NCBR/2018.

Institutional Review Board Statement: Not applicable.

Informed Consent Statement: Not applicable.

Data Availability Statement: The data are presented within the manuscript, Appendices A-D, as well as the obtained nucleotide sequences are deposited in the GenBank repository (https:/ / www. ncbi.nlm.nih.gov/genbank/) under the following accession numbers: MW255650 (Rhodococcus sp. B12/18), MW255651 (Pseudomonas sp. B37/18), MW255652 (Arthrobacter sp. B58/18), MW255653 (Rhodococcus sp. B75/18).

Acknowledgments: This research was funded by the National Centre for Research and Development in frame of the project BIOSTRATEG, contract number BIOSTRATEG3/344433/16/NCBR/2018.

Conflicts of Interest: The authors declare no conflict of interest.

\section{Abbreviations}

$\begin{array}{ll}\text { PCA } & \text { Plate count agar } \\ \text { PDA } & \text { Potato dextrose agar } \\ \text { IF-A } & \text { Biolog }^{\circledR} \text { GEN III Inoculating Fluid } \\ \text { D } & \text { Drying } \\ \text { VD } & \text { Vacuum drying } \\ \text { LF } & \text { Lyophilization } \\ \text { CFU } & \text { Colony-forming units } \\ \text { NN } & \text { No naturalization } \\ \text { R } & \text { Roots naturalization } \\ \text { RW } & \text { Roots + watering naturalization } \\ \text { W } & \text { Watering naturalization } \\ \text { NCBI } & \text { National Centre for Biotechnology Information } \\ \text { RCF } & \text { Relative centrifugal force } \\ \text { RPM } & \text { Rotations per minute } \\ \text { TDR } & \text { Time Domain Reflectometry }\end{array}$

\section{Appendix A}

Table A1. Design of plant pot experiment including pathosystems, naturalization strategies and repetitions.

\begin{tabular}{|c|c|c|c|c|c|}
\hline & Pathosystem & Naturalization Strategy & \multicolumn{3}{|c|}{ Repetitions } \\
\hline 1 & without pathogens & no naturalization & a & $\mathrm{b}$ & c \\
\hline 2 & without pathogens & bacteria roots & a & $\mathrm{b}$ & c \\
\hline 5 & without pathogens & bacteria roots plus watering & a & $\mathrm{b}$ & c \\
\hline 8 & without pathogens & bacteria watering & a & $\mathrm{b}$ & c \\
\hline 11 & Infection Botrytis cinerea G277/18 & no naturalization & a & $\mathrm{b}$ & C \\
\hline 12 & Infection Botrytis cinerea G277/18 & bacteria roots & a & $\mathrm{b}$ & c \\
\hline 15 & Infection Botrytis cinerea G277/18 & bacteria roots plus watering & a & $\mathrm{b}$ & c \\
\hline 18 & Infection Botrytis cinerea G277/18 & bacteria watering & a & $\mathrm{b}$ & c \\
\hline 21 & Infection Verticillium sp. G296/18 & no naturalization & a & $\mathrm{b}$ & c \\
\hline 22 & Infection Verticillium sp. G296/18 & bacteria roots & a & $\mathrm{b}$ & c \\
\hline 25 & Infection Verticillium sp. G296/18 & bacteria roots plus watering & a & $\mathrm{b}$ & c \\
\hline 28 & Infection Verticillium sp. G296/18 & bacteria watering & a & $\mathrm{b}$ & c \\
\hline
\end{tabular}


Table A1. Cont.

\begin{tabular}{|c|c|c|c|c|c|}
\hline & Pathosystem & Naturalization Strategy & \multicolumn{3}{|c|}{ Repetitions } \\
\hline 31 & Infection Colletotrichum sp. G172/18 & no naturalization & a & $\mathrm{b}$ & c \\
\hline 32 & Infection Colletotrichum sp. G172/18 & bacteria roots & a & $\mathrm{b}$ & c \\
\hline 35 & Infection Colletotrichum sp. G172/18 & bacteria roots plus watering & a & $\mathrm{b}$ & c \\
\hline 38 & Infection Colletotrichum sp. G172/18 & bacteria watering & a & $\mathrm{b}$ & c \\
\hline 41 & Infection Phytophthora sp. G402/18 & no naturalization & a & $\mathrm{b}$ & c \\
\hline 42 & Infection Phytophthora sp. G402/18 & bacteria roots & a & $\mathrm{b}$ & c \\
\hline 45 & Infection Phytophthora sp. G402/18 & bacteria roots plus watering & a & $\mathrm{b}$ & c \\
\hline 48 & Infection Phytophthora sp. G402/18 & bacteria watering & a & $\mathrm{b}$ & c \\
\hline 51 & Infection with all 4 pathogens & no naturalization & a & $\mathrm{b}$ & c \\
\hline 52 & Infection with all 4 pathogens & bacteria roots & a & $\mathrm{b}$ & c \\
\hline 55 & Infection with all 4 pathogens & bacteria roots plus watering & a & $\mathrm{b}$ & c \\
\hline 58 & Infection with all 4 pathogens & bacteria watering & a & $b$ & c \\
\hline
\end{tabular}

\section{Appendix B}

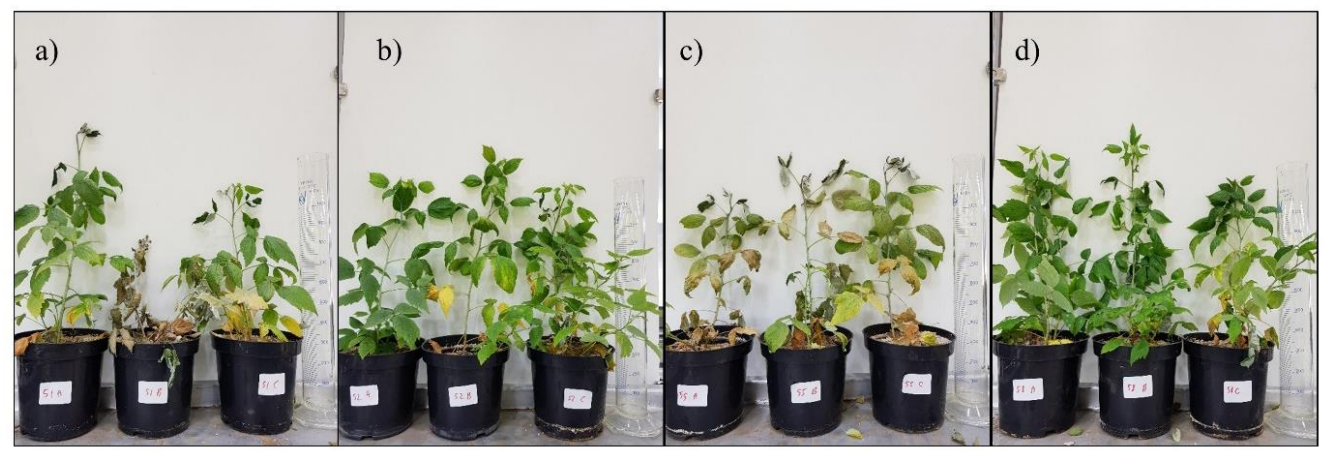

Figure A1. Effect of plant growth stimulation caused by the different naturalization strategies on plants infected with fungal and fungal-like plant pathogens Botrytis cinerea (G277/18), Colletotrichum sp. (G172/18), Phytophthora sp. (G408/18), and Verticillium sp. (G296/18): (a) no naturalization strategy, (b) naturalization of roots, (c) roots naturalization and naturalization watering, (d) naturalization watering.

\section{Appendix C}

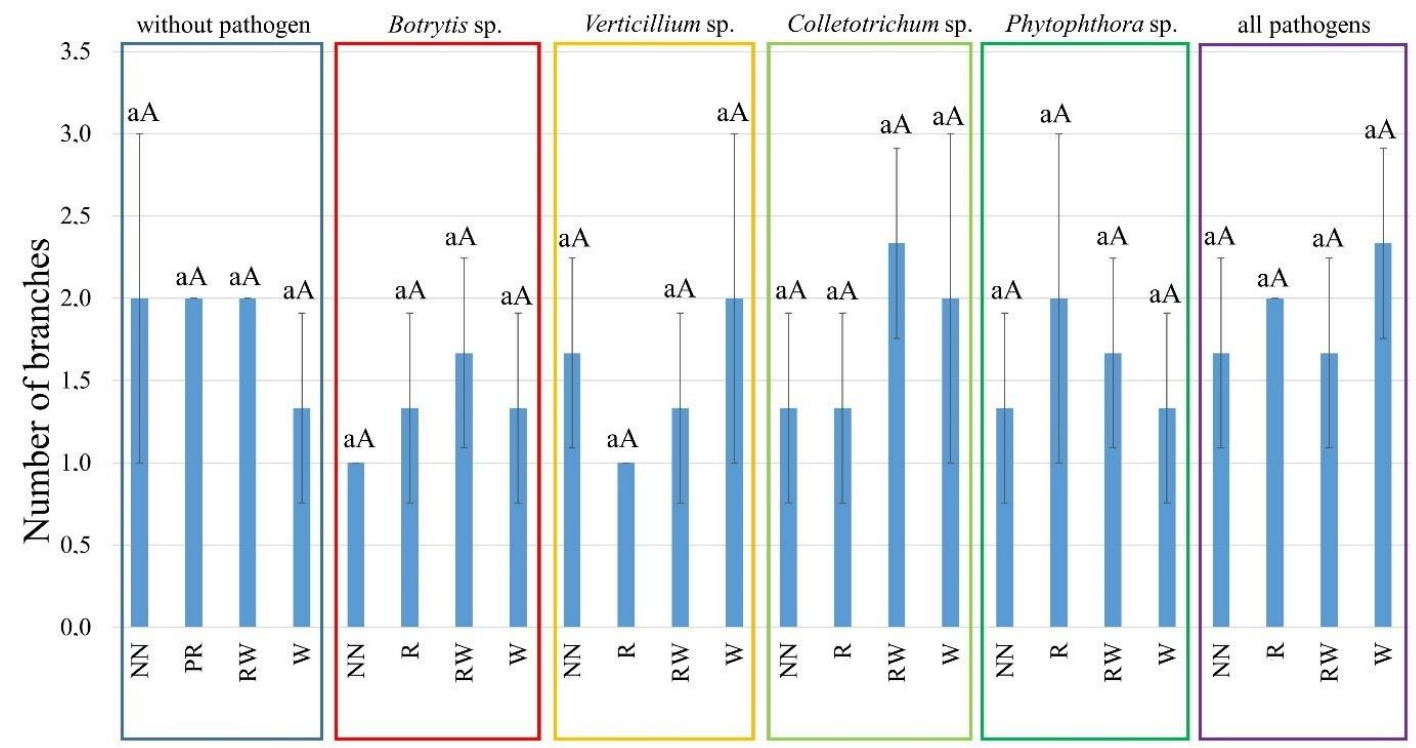

Figure A2. The early effect of the bacterial consortium on Polana raspberry plant growth in the pot experiment depended on 
the pathosystem and naturalization strategy applied. The average number of stems, according to pathosystems Botrytis cinerea, Verticillium sp., Colletotrichum acutatum, Phytophthora sp., and all pathogens (Botrytis, Verticillium, Colletotrichum, Phytophthora) and without pathogens, within different biopreparation application strategies: no naturalization (NN), root inoculations (R), root inoculations and watering (RW), and watering (W). Error bars indicate a standard deviation, $n=3$, different lowercase letters above the bars indicate differences among the particular pathosystem, and different capital letters above the bars indicate differences among the particular naturalization strategies (according to ANOVA with $p<0.05$ ).

\section{Appendix D}

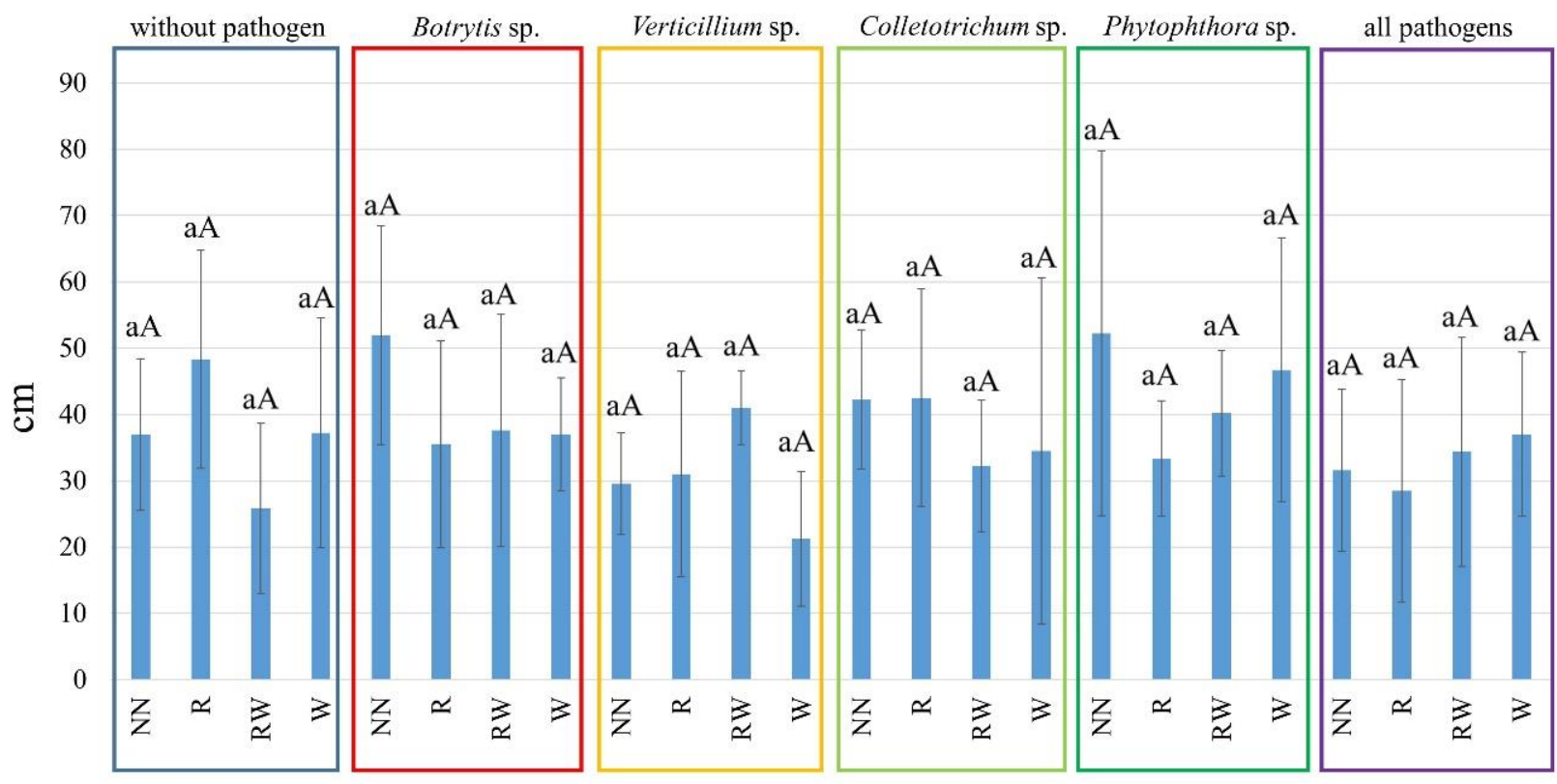

Figure A3. The early effect of the bacterial consortium on Polana raspberry plant growth in the pot experiment depended on the pathosystem and naturalization strategy applied. The average length of the stems, according to pathosystems Botrytis cinerea, Verticillium sp., Colletotrichum acutatum, Phytophthora sp., and all pathogens (Botrytis, Verticillium, Colletotrichum, Phytophthora) and without pathogens, within different biopreparation application strategies: no naturalization (NN), root inoculations (R), root inoculations and watering (RW), and watering (W). Error bars indicate a standard deviation, $n=3$, different lowercase letters above the bars indicate differences among the particular pathosystem, and different capital letters above the bars indicate differences among the particular naturalization strategies (according to ANOVA with $p<0.05$ ).

\section{References}

1. Pylak, M.; Oszust, K.; Frac, M. Review report on the role of bioproducts, biopreparations, biostimulants and microbial inoculants in organic production of fruit. Rev. Environ. Sci. Biotechnol. 2019, 18, 597-616. [CrossRef]

2. Baćmaga, M.; Wyszkowska, J.; Kucharski, J. The influence of chlorothalonil on the activity of soil microorganisms and enzymes. Ecotoxicology 2018, 27, 1188-1202. [CrossRef] [PubMed]

3. EU Council Regulation (EC) No 834/2007. Available online: https://eur-lex.europa.eu/eli/reg/2007/834/oj. (accessed on 25 October 2021).

4. Du Jardin, P. Plant biostimulants: Definition, concept, main categories and regulation. Sci. Hortic. 2015, 196, 3-14. [CrossRef]

5. Pylak, M.; Oszust, K.; Frąc, M. Searching for new beneficial bacterial isolates of wild raspberries for biocontrol of phytopathogensantagonistic properties and functional characterization. Int. J. Mol. Sci. 2020, 21, 9361. [CrossRef] [PubMed]

6. Marjańska-Cichon, B.; Sapieha-Waszkiewicz, A.; Miętkiewski, R. Effectiveness of biofungicides bioczos S and polyversum used to soak strawberry cuttings in verticillium wilt disease control. J. Plant Prot. Res. 2009, 49, 395-398. [CrossRef]

7. Rey, P.; Le Floch, G.; Benhamou, N.; Tirilly, Y. Pythium oligandrum biocontrol: Its relationships with fungi and plants. In Plant-Microbe Interactions; Ait Barka, E., Clément, C., Eds.; Research Signpost: Trivandrum, India, 2008; pp. 43-67, ISBN 978-81-308-0212-1.

8. Soytong, K.; Srinon, W.; Rattanacherdchai, K.; Kanokmedhakul, S.; Kanokmedhakul, K. Application of antagonistic fungi to control anthracnose disease of grape. J. Agric. Technol. 2005, 1, 33-41.

9. Waschina, S.; D'Souza, G.; Kost, C.; Kaleta, C. Metabolic network architecture and carbon source determine metabolite production costs. FEBS J. 2016, 283, 2149-2163. [CrossRef] [PubMed] 
10. Oszust, K.; Pawlik, A.; Janusz, G.; Ziemiński, K.; Cyran, M.; Siczek, A.; Gryta, A.; Bilinska-Wielgus, N.; Frac, M. Characterization and influence of a multi-enzymatic biopreparation for biogas yield enhancement. BioResources 2017, 12, 6187-6206. [CrossRef]

11. Singh, V.; Haque, S.; Niwas, R.; Srivastava, A.; Pasupuleti, M.; Tripathi, C.K.M. Strategies for fermentation medium optimization: An in-depth review. Front. Microbiol. 2017, 7, 2087. [CrossRef] [PubMed]

12. Oszust, K.; Cybulska, J.; Frąc, M. How do trichoderma genus fungi win a nutritional competition battle against soft fruit pathogens? A report on niche overlap nutritional potentiates. Int. J. Mol. Sci. 2020, 21, 4235. [CrossRef]

13. De Souza, R.; Ambrosini, A.; Passaglia, L.M.P. Plant growth-promoting bacteria as inoculants in agricultural soils. Genet. Mol. Biol. 2015, 38, 401-419. [CrossRef] [PubMed]

14. Ben-David, A.; Davidson, C.E. Estimation method for serial dilution experiments. J. Microbiol. Methods 2014, 107, $214-221$. [CrossRef] [PubMed]

15. Leslie, S.B.; Israeli, E.; Lighthart, B.; Crowe, J.H.; Crowe, L.M. Trehalose and sucrose protect both membranes and proteins in intact bacteria during drying. Appl. Environ. Microbiol. 1995, 61, 3592-3597. [CrossRef] [PubMed]

16. Peiren, J.; Buyse, J.; De Vos, P.; Lang, E.; Clermont, D.; Hamon, S.; Bégaud, E.; Bizet, C.; Pascual, J.; Ruvira, M.A.; et al. Improving survival and storage stability of bacteria recalcitrant to freeze-drying: A coordinated study by European culture collections. Appl. Microbiol. Biotechnol. 2015, 99, 3559-3571. [CrossRef] [PubMed]

17. Ostrowska, A.; Gawliński, S.; Szczubiałka, Z. Methods of Analysis and Assessment of Soil and Plant Properties; Environmental Protection Institute: Warsaw, Poland, 1991.

18. Thalmann, A. Zur methodik der Bestimmung der Dehydrogenase activität im Boden Mittels Triphenyltetrazoliumchlorid (TTC). Landwirtsch Forsch 1968, 21, 249-258.

19. Alef, K. Dehydrogenase activity. In Applied Soil Microbiology and Biochemistry; Alef, K., Nannipieri, P., Eds.; Academic Press: London, UK, 1995; pp. 228-231.

20. Lívanský, K. Optimization of costs per unit of microbial biomass produced in a batch culture. Folia Microbiol. 1980, 25, 238-241. [CrossRef] [PubMed]

21. Vijayakumari, S.J.; Sasidharannair, N.K.; Nambisan, B.; Mohandas, C. Optimization of media and temperature for enhanced antimicrobial production by bacteria associated with Rhabditis sp. Iran. J. Microbiol. 2013, 5, 136-141. [PubMed]

22. Chen, X.H.; Lou, W.Y.; Zong, M.H.; Smith, T.J. Optimization of culture conditions to produce high yields of active Acetobacter sp. CCTCC M209061 cells for anti-Prelog reduction of prochiral ketones. BMC Biotechnol. 2011, 11, 110. [CrossRef]

23. Alizadeh, H.; Sharifi-Tehrani, A.; Hedjaroude, G.A. Evaluation of the effects of chemical versus biological control on Botrytis cinerea agent of gray mould disease of strawberry. Commun. Agric. Appl. Biol. Sci. 2007, 72, 795-800.

24. Nancib, N.; Branlant, C.; Boudrant, J. Metabolic roles of peptone and yeast extract for the culture of a recombinant strain of Escherichia coli. J. Ind. Microbiol. 1991, 8, 165-169. [CrossRef]

25. Bollmann, A.; Bär-Gilissen, M.J.; Laanbroek, H.J. Growth at low ammonium concentrations and starvation response as potential factors involved in niche differentiation among ammonia-oxidizing bacteria. Appl. Environ. Microbiol. 2002, 68, $4751-4757$. [CrossRef] [PubMed]

26. Hayat, R.; Ali, S.; Amara, U.; Khalid, R.; Ahmed, I. Soil beneficial bacteria and their role in plant growth promotion: A review. Ann. Microbiol. 2010, 60, 579-598. [CrossRef]

27. Verhamme, D.T.; Prosser, J.I.; Nicol, G.W. Ammonia concentration determines differential growth of ammonia-oxidising archaea and bacteria in soil microcosms. ISME J. 2011, 5, 1067-1071. [CrossRef]

28. Rudrappa, T.; Czymmek, K.J.; Paré, P.W.; Bais, H.P. Root-secreted malic acid recruits beneficial soil bacteria. Plant Physiol. 2008, 148, 1547-1556. [CrossRef]

29. Konopka, J.B. N-Acetylglucosamine Functions in Cell Signaling. Scientifica 2012, 2012, 489208. [CrossRef]

30. Uehara, T.; Park, J.T. The N-acetyl-D-glucosamine kinase of Escherichia coli and its role in murein recycling. J. Bacteriol. 2004, 186, 7273-7279. [CrossRef]

31. Otto, C.; Yovkova, V.; Barth, G. Overproduction and secretion of $\alpha$-ketoglutaric acid by microorganisms. Appl. Microbiol. Biotechnol. 2011, 92, 689-695. [CrossRef]

32. Liu, S.; He, L.; Yao, K. The antioxidative function of alpha-ketoglutarate and its applications. BioMed Res. Int. 2018, $2018,3408467$. [CrossRef]

33. Dover, S.; Halpern, Y.S. Utilization of -aminobutyric acid as the sole carbon and nitrogen source by Escherichia coli K-12 mutants. J. Bacteriol. 1972, 109, 835-843. [CrossRef]

34. Kaspar, H.F.; Mountfort, D.O.; Pybus, V. Degradation of gamma-aminobutyric acid (GABA) by marine microorganisms. FEMS Microbiol. Lett. 1991, 85, 313-318. [CrossRef]

35. Bauer, S.A.W.; Schneider, S.; Behr, J.; Kulozik, U.; Foerst, P. Combined influence of fermentation and drying conditions on survival and metabolic activity of starter and probiotic cultures after low-temperature vacuum drying. J. Biotechnol. 2012, 159, 351-357. [CrossRef] [PubMed]

36. Kumar, K.N.; Mallik, S.; Sarkar, K. Role of freeze-drying in the presence of mannitol on the echogenicity of echogenic liposomes. J. Acoust. Soc. Am. 2017, 142, 3670-3676. [CrossRef]

37. Wessman, P.; Håkansson, S.; Leifer, K.; Rubino, S. Formulations for freeze-drying of bacteria and their influence on cell survival. J. Vis. Exp. 2013, 78, 4058. [CrossRef] 
38. Peterson, B.W.; Sharma, P.K.; van der Mei, H.C.; Busscher, H.J. Bacterial cell surface damage due to centrifugal compaction. Appl. Environ. Microbiol. 2012, 78, 120-125. [CrossRef]

39. Naylor, D.; Coleman-Derr, D. Drought stress and root-associated bacterial communities. Front. Plant Sci. 2018, 8, 2223. [CrossRef] [PubMed]

40. Mille, Y.; Beney, L.; Gervais, P. Viability of Escherichia coli after combined osmotic and thermal treatment: A plasma membrane implication. Biochim. Biophys. Acta-Biomembr. 2002, 1567, 41-48. [CrossRef]

41. Prasad, J.; McJarrow, P.; Gopal, P. Heat and osmotic stress responses of probiotic Lactobacillus rhamnosus HN001 (DR20) in relation to viability after drying. Appl. Environ. Microbiol. 2003, 69, 917-925. [CrossRef]

42. Galal Mors, H.E. Diatomite: Its Characterization, Modifications and Applications. Asian J. Mater. Sci. 2010, 2, 121-136. [CrossRef]

43. Angin, I.; Kose, M.; Aslantas, R. Effect of diatomite on growth of strawberry. Pak. J. Bot. 2011, 43, 573-577.

44. Olsson, C.; Jansson, H.; Swenson, J. The Role of Trehalose for the Stabilization of Proteins. J. Phys. Chem. B 2016, $120,4723-4731$. [CrossRef]

45. Reina-Bueno, M.; Argandoña, M.; Salvador, M.; Rodríguez-Moya, J.; Iglesias-Guerra, F.; Csonka, L.N.; Nieto, J.J.; Vargas, C. Role of trehalose in salinity and temperature tolerance in the model halophilic bacterium chromohalobacter salexigens. PLoS ONE 2012, 7, e33587. [CrossRef] [PubMed]

46. Crowe, L.M.; Reid, D.S.; Crowe, J.H. Is trehalose special for preserving dry biomaterials? Biophys. J. 1996, 71, $2087-2093$. [CrossRef]

47. Schoebitz, M.; Simonin, H.; Poncelet, D. Starch filler and osmoprotectants improve the survival of rhizobacteria in dried alginate beads. J. Microencapsul. 2012, 29, 532-538. [CrossRef] [PubMed]

48. Hanley, M.E.; Fenner, M.; Whibley, H.; Darvill, B. Early plant growth: Identifying the end point of the seedling phase. New Phytol. 2004, 163, 61-66. [CrossRef] [PubMed]

49. Matsuo, N.; Fukami, K.; Tsuchiya, S. Effects of early planting and cultivars on the yield and agronomic traits of soybeans grown in southwestern Japan. Plant Prod. Sci. 2016, 19, 370-380. [CrossRef]

50. De Luis, M.; Verdú, M.; Raventós, J. Early to rise makes a plant healthy, wealthy, and wise. Ecology 2008, 89, 3061-3071. [CrossRef]

51. Oszust, K.; Frąc, M. First report on the microbial communities of the wild and planted raspberry rhizosphere-A statement on the taxa, processes and a new indicator of functional diversity. Ecol. Indic. 2020, 121, 107117. [CrossRef]

52. Mazur, R.; Ryżak, M.; Sochan, A.; Marciszuk, K.; Beczek, M.; Lamorski, K.; Bieganowski, A. Surface deformation and displacement of bed elements during splash-Model tests. CATENA 2020, 185, 104277. [CrossRef]

53. Salazar, S.; Sánchez, L.E.; Alvarez, J.; Valverde, A.; Galindo, P.; Igual, J.M.; Peix, A.; Santa-Regina, I. Correlation among soil enzyme activities under different forest system management practices. Ecol. Eng. 2011, 37, 1123-1131. [CrossRef]

54. Moeskops, B.; Sukristiyonubowo; Buchan, D.; Sleutel, S.; Herawaty, L.; Husen, E.; Saraswati, R.; Setyorini, D.; De Neve, S. Soil microbial communities and activities under intensive organic and conventional vegetable farming in West Java, Indonesia. Appl. Soil Ecol. 2010, 45, 112-120. [CrossRef]

55. Pająk, M.; Błońska, E.; Frąc, M.; Oszust, K. Functional Diversity and Microbial Activity of Forest Soils that Are Heavily Contaminated by Lead and Zinc. Water Air Soil Pollut. 2016, 227, 348. [CrossRef] [PubMed]

56. Schiavon, M.; Ertani, A.; Nardi, S. Effects of an alfalfa protein hydrolysate on the gene expression and activity of enzymes of the tricarboxylic acid (TCA) cycle and nitrogen metabolism in Zea mays L. J. Agric. Food Chem. 2008, 56, 11800-11808. [CrossRef]

57. Mithöfer, A.; Maffei, M.E. General Mechanisms of Plant Defense and Plant Toxins. In Plant Toxins; Carlini, C.R., Ligabue-Braun, R., Gopalakrishnakone, P., Eds.; Springer: Dordrecht, The Netherlands, 2017; pp. 3-24. ISBN 978-94-007-6464-4.

58. Spann, T.M.; Schumann, A.W. The Role of Plant Nutrients in Disease Development with Emphasis on Citrus and Huanglongbing. Proc. Fla. State Hort. Sci. 2009, 122, 169-171.

59. Dordas, C. Role of nutrients in controlling the plant diseases in sustainable agriculture. Agron. Sustain. Dev. 2008, 28, 33-46. [CrossRef]

60. Fatima, U.; Senthil-Kumar, M. Plant and pathogen nutrient acquisition strategies. Front. Plant Sci. 2015, 6, 750. [CrossRef]

61. von Fircks, Y.; Ericsson, T.; Sennerby-Forsse, L. Seasonal variation of macronutrients in leaves, stems and roots of Salix dasyclados Wimm. grown at two nutrient levels. Biomass Bioenergy 2001, 21, 321-334. [CrossRef]

62. He, M.; Zhang, K.; Tan, H.; Hu, R.; Su, J.; Wang, J.; Huang, L.; Zhang, Y.; Li, X. Nutrient levels within leaves, stems, and roots of the xeric species Reaumuria soongorica in relation to geographical, climatic, and soil conditions. Ecol. Evol. 2015, 5, 1494-1503. [CrossRef] [PubMed]

63. Santos, E.F.; Macedo, F.G.; Zanchim, B.J.; Camacho, M.A.; Lavres, J. Macronutrients uptake rate and biomass partitioning during early growth of Jatropha plants. Rev. Cienc. Agron. 2017, 48, 565-575. [CrossRef]

64. Kalayu, G. Phosphate solubilizing microorganisms: Promising approach as biofertilizers. Int. J. Agron. 2019, $2019,4917256$. [CrossRef]

65. Scarlett, K.; Guest, D.; Daniel, R. Elevated soil nitrogen increases the severity of dieback due to Phytophthora cinnamomi. Australas. Plant Pathol. 2013, 42, 155-162. [CrossRef] 